OPEN ACCESS

Edited by:

Taher Darreh-Shori,

Karolinska Institute (KI), Sweden

Reviewed by:

Caroline Louise Benn, Astex Pharmaceuticals (UK), United Kingdom

Arianna Bellucci,

University of Brescia, Italy

*Correspondence:

R. Jane Rylett

jane.rylett@schulich.uwo.ca

Received: 29 August 2017 Accepted: 19 October 2017 Published: 07 November 2017

Citation:

Cuddy LK, Seah C, Pasternak SH and Rylett RJ (2017) Amino-Terminal $\beta$-Amyloid Antibody Blocks $\beta$-Amyloid-Mediated Inhibition of the High-Affinity Choline Transporter

Front. Mol. Neurosci. 10:361. doi: 10.3389/fnmol.2017.00361

\section{Amino-Terminal $\beta$-Amyloid Antibody Blocks $\beta$-Amyloid-Mediated Inhibition of the High-Affinity Choline Transporter CHT}

\author{
Leah K. Cuddy ${ }^{1,2,3}$, Claudia Seah ${ }^{1}$, Stephen H. Pasternak ${ }^{1,4}$ and R. Jane Rylett ${ }^{1,2 *}$ \\ ${ }^{1}$ Molecular Medicine Research Laboratories, Robarts Research Institute, University of Western Ontario, London, ON, \\ Canada, ${ }^{2}$ Department of Physiology and Pharmacology, Schulich School of Medicine \& Dentistry, University of Western \\ Ontario, London, ON, Canada, ${ }^{3}$ Department of Neurology, Feinberg School of Medicine, Northwestern University, Chicago, \\ IL, United States, ${ }^{4}$ Department of Clinical Neurological Sciences, Schulich School of Medicine \& Dentistry, University of \\ Western Ontario, London, ON, Canada
}

Alzheimer's disease (AD) is a common age-related neurodegenerative disorder that is characterized by progressive cognitive decline. The deficits in cognition and attentional processing that are observed clinically in $A D$ are linked to impaired function of cholinergic neurons that release the neurotransmitter acetylcholine (ACh). The high-affinity choline transporter $(\mathrm{CHT})$ is present at the presynaptic cholinergic nerve terminal and is responsible for the reuptake of choline produced by hydrolysis of ACh following its release. Disruption of $\mathrm{CHT}$ function leads to decreased choline uptake and ACh synthesis, leading to impaired cholinergic neurotransmission. We report here that cell-derived $\beta$-amyloid peptides $(A \beta)$ decrease choline uptake activity and cell surface $\mathrm{CHT}$ protein levels in SH-SY5Y neural cells. Moreover, we make the novel observation that the amount of $\mathrm{CHT}$ protein localizing to early endosomes and lysosomes is decreased significantly in cells that have been treated with cell culture medium that contains $A \beta$ peptides released from neural cells. The A $\beta$-mediated loss of $\mathrm{CHT}$ proteins from lysosomes is prevented by blocking lysosomal degradation of $\mathrm{CHT}$ with the lysosome inhibitor bafilomycin $\mathrm{A}_{1}\left(\mathrm{Baf}_{1}\right)$. Baf $\mathrm{A}_{1}$ also attenuated the $\mathrm{A} \beta$-mediated decrease in $\mathrm{CHT}$ cell surface expression. Interestingly, however, lysosome inhibition did not block the effect of $A \beta$ on $C H T$ activity. Importantly, neutralizing $A \beta$ using an anti-A $\beta$ antibody directed at the $N$-terminal amino acids $1-16$ of $A \beta$, but not by an antibody directed at the mid-region amino acids 22-35 of $A \beta$, attenuates the effect of $A \beta$ on CHT activity and trafficking. This indicates that a specific $\mathrm{N}$-terminal $A \beta$ epitope, or specific conformation of soluble $A \beta$, may impair $\mathrm{CHT}$ activity. Therefore, $A \beta$ immunotherapy may be a more effective therapeutic strategy for slowing the progression of cognitive decline in $\mathrm{AD}$ than therapies designed to promote $\mathrm{CHT}$ cell surface levels.

Keywords: protein trafficking, cholinergic, $\beta$-amyloid, Alzheimer's disease

Abbreviations: $A \beta, \beta$-amyloid; $A C h$, acetylcholine; AD, Alzheimer's disease; ANOVA, analysis of variance; APP, amyloid precursor protein; $\mathrm{BafA}_{1}$, bafilomycin A1; CHT, high-affinity choline transporter; HC-3, hemicholinium-3; KRH, Krebs-Ringer-HEPES. 


\section{INTRODUCTION}

Alzheimer's disease $(\mathrm{AD})$ is a neurodegenerative disorder defined by progressive and irreversible cognitive decline. Cognitive and attentional processes impaired in $\mathrm{AD}$ are mediated by cholinergic neurons with release of the neurotransmitter acetylcholine (ACh; Sarter and Parikh, 2005). After binding to receptors, $\mathrm{ACh}$ is hydrolyzed by acetylcholinesterase to choline and acetate with choline then taken up into cholinergic presynaptic terminals by the high-affinity choline transporter (CHT) to serve as substrate for ACh synthesis (Haga and Noda, 1973; Kuhar and Murrin, 1978; Rylett and Schmidt, 1993). Recycling of CHT proteins between the cell surface and endosomal compartments maintains plasma membrane CHT levels, thereby regulating choline uptake activity (Black and Rylett, 2012). CHT proteins internalize constitutively from the plasma membrane by a clathrin-dependent mechanism and either recycle back to the cell surface or move through late endosomes to lysosomes for degradation (Cuddy et al., 2012).

Two major features of $\mathrm{AD}$ pathology are dysfunction of cholinergic transmission early in the course of the disease and the progressive accumulation of $\beta$-amyloid (A $\beta)$ peptides produced by cleavage of amyloid precursor protein (APP), with a link having been established between these two aspects of $\mathrm{AD}$ pathology. Cholinergic transmission promotes the non-amyloidogenic $\alpha$-cleavage of APP through ACh stimulation of muscarinic receptors (Nitsch et al., 1992), while APP plays a role in cholinergic neurons by regulating the presynaptic localization of CHT proteins and their internalization from the cell surface (Wang et al., 2007). Importantly, it has been shown in experiments using synthetic preparations of $A \beta$ peptides that oligomeric $\mathrm{A} \beta$ can negatively regulate $\mathrm{ACh}$ synthesis and release by inhibiting high-affinity choline uptake (Pedersen et al., 1996; Auld et al., 1998; Kar et al., 1998; Parikh et al., 2014); one study reported enhanced choline uptake activity in synaptosomes and neural cells exposed acutely to oligomeric $\mathrm{A} \beta_{1-42}$, but links this to reduced ACh release (Bales et al., 2006). Following depolarization of synaptosomes, incubation with $\mathrm{A} \beta_{1-40}$ decreases binding of the $\mathrm{CHT}$ ligand $\left[{ }^{3} \mathrm{H}\right]$ hemicholinium$3\left(\left[{ }^{3} \mathrm{H}\right] \mathrm{HC}-3\right)$, giving an indirect measurement of transporter reduction at the cell surface (Kristofiková et al., 2001). Thus, accumulation of $\mathrm{A} \beta$ peptides in brain may inhibit $\mathrm{CHT}$ activity, decreasing $\mathrm{ACh}$ synthesis and impairing cholinergic transmission.

Evidence suggests that soluble $\mathrm{A} \beta$ peptides promote the disease process by several mechanisms, including disrupting synaptic transmission and impairing long-term potentiation (Walsh et al., 2002; Townsend et al., 2006; Chen et al., 2013). Accordingly, passive immunization approaches using $A \beta$ antibodies to neutralize and facilitate clearance of soluble $A \beta$ peptides are being evaluated clinically for the treatment of $\mathrm{AD}$ (Schenk, 2002; Panza et al., 2011). Antibodies targeting different epitopes in the $\mathrm{N}$-terminus, mid-region and $\mathrm{C}$-terminus of $\mathrm{A} \beta$ peptides have been designed, with most preclinical studies focusing on $\mathrm{N}$-terminal $\mathrm{A} \beta$ antibodies such as Bapineuzumab (Miles et al., 2013) and mid-region $A \beta$ antibodies such as
Solanezumab (m266; DeMattos et al., 2001). Some A $\beta$ antibodies can bind to and effectively reduce either soluble and fibrillar forms of $A \beta$, thereby preventing synaptic degeneration and cognitive deficits in animal models of $\mathrm{AD}$ (Bard et al., 2000; Schroeter et al., 2008; Pul et al., 2011; Zago et al., 2012).

The purpose of the present study was to investigate the effect of $A \beta$ peptides released into conditioned medium (CM) from neural cells expressing Swedish mutant APP $\left(\mathrm{CM}-\mathrm{APP}_{\text {Swe }}\right)$ on CHT trafficking and activity, and to determine whether this is altered by anti-A $\beta$ antibodies. We found recently that expression of $\mathrm{APP}_{\text {Swe }}$ in neural cells decreases $\mathrm{CHT}$ function when compared to wild-type APP with this related to increased $\mathrm{APP}_{\text {Swe }}$ processing (Cuddy et al., 2015). We now make the novel observation that treatment of neural cells with $\mathrm{CM}$ that contains $\mathrm{A} \beta$ peptides from cells expressing $\mathrm{APP}_{\text {Swe }}$ decreases CHT co-localization with the early endosome marker EEA1 and lysosome marker LAMP-1, suggesting that $\mathrm{A} \beta$-mediated inhibition of $\mathrm{CHT}$ function is related to a loss of CHT proteins from endocytic recycling compartments. In support of this, we found that the lysosome inhibitor bafilomycin A1 $\left(\mathrm{BafA}_{1}\right)$ attenuates $\mathrm{A} \beta$-mediated inhibition of $\mathrm{CHT}$ cell surface expression. Interestingly, however, lysosome inhibition did not block the effect of $\mathrm{A} \beta$ on $\mathrm{CHT}$ activity. Importantly, inhibition of $\mathrm{CHT}$ function by $\mathrm{A} \beta$ peptides was blocked by an antibody directed at the N-terminal amino acids 1-16 of $\mathrm{A} \beta$ (anti-A $\beta[1-16]$ ), but not by an antibody directed at the mid-region amino acids $22-35$ of $A \beta$ (anti-A $\beta[22-35]$ ).

\section{MATERIALS AND METHODS}

\section{Materials}

Rabbit anti- $\beta$-amyloid (22-35) antibody (anti-A $\beta[22-35])$ and protease inhibitor cocktail were from Sigma-Aldrich (St. Louis, MO, USA). Anti- $\beta$-amyloid 1-16 (6E10) mouse monoclonal antibody (anti-A $\beta[1-16]$ ) was from Covance (Princeton, NJ, USA). Rabbit polyclonal anti-actin antibody was from Santa Cruz Biotechnology (Santa Cruz, CA, USA). [Methyl ${ }^{3} \mathrm{H}$ ]Choline chloride $(88.5 \mathrm{Ci} / \mathrm{mmol})$ was from PerkinElmer Life Sciences (Boston, MA, USA). SH-SY5Y human neuroblastoma cells were from American Type Culture Collection (Manassus, VA, USA), and Invitrogen (Burlington, ON, Canada) supplied fetal bovine serum (FBS), Lipofectamine 2000, OptiMEM, culture media and reagents, AlexaFluor-488 donkey anti-mouse IgG and AlexaFluor-647 goat anti-rabbit IgG antibodies. Enhanced ChemiLuminescence (ECL) immunoblot reagent, Protein G Sepharose and Biodegradable Scintillant were from GE Healthcare Life Sciences (Baie d'Urfé, QC, Canada). Clarity ECL was from BioRad (Mississauga, ON, Canada). Polyclonal CHT antibody was raised in rabbits to the antigenic peptide DVDSSPEGSGTEDNLQ conserved at the C-terminus of human and rat CHT (Genemed Synthesis, San Antonio, TX, USA); this peptide was conjugated to KLH carrier protein by an N-terminal cysteine residue (Pinthong et al., 2008). CHT-specific IgG was affinity-purified in our laboratory from crude antiserum on NHS-Sepharose (GE 
Healthcare) to which antigenic peptide had been coupled as the binding element. Peroxidase-conjugated goat anti-rabbit $\operatorname{IgG}$ and peroxidase-conjugated goat anti-mouse $\operatorname{IgG}$ were from Jackson ImmunoResearch Laboratories (West Grove, PA, USA).

\section{Cell Transfection and Selection of Cell Lines}

Full-length rat CHT cDNA ligated to pSPORT was a gift from Dr. T. Okuda (Okuda and Haga, 2000); a FLAG-epitope tag (DYKDDDDK) was added to the amino-terminus by PCR and the resulting cDNA ligated to pcDNA3.1. SH-SY5Y cells were transfected with FLAG-CHT plasmid by Lipofectamine 2000. Stable transformants (SY5Y-CHT cells) were selected using $500 \mu \mathrm{g} / \mathrm{ml}$ geneticin (G418) for 4 weeks, and then grown in complete medium (DMEM containing 10\% FBS, $100 \mathrm{U} / \mathrm{ml}$ penicillin, and $100 \mu \mathrm{g} / \mathrm{ml}$ each of streptomycin and G418). SH-SY5Y cell differentiation was induced by addition of 10 $\mu$ M RA (all-trans-retinoic acid) for 3 days, during which time cells underwent morphological and biochemical differentiation. For transient transfection, cells were treated with RA for 3 days, then immediately before transfection culture medium was changed to complete medium without antibiotics. At the time of transfection, a ratio of $1 \mu \mathrm{g}$ plasmid DNA in $100 \mu \mathrm{l}$ OptiMEM was added to $100 \mu$ l OptiMEM containing $2.5 \mu$ l Lipofectamine 2000, then incubated for $20 \mathrm{~min}$ at room temperature. This mixture was added to cell monolayers in antibiotic-free medium and incubated for 4-6 h. At the end of this incubation, culture medium was replaced with complete medium containing RA and grown for an additional $24 \mathrm{~h}$.

\section{Preparation of Conditioned Medium (CM)}

SY5Y-CHT cells were grown to near confluency on $100 \mathrm{~mm}$ dishes in complete medium with $10 \mu \mathrm{M}$ RA for 3 days. Cells were transiently transfected with $9 \mu \mathrm{g}$ per dish of either $\mathrm{APP}_{\text {Swe }}$ plasmid DNA or the empty vector pcDNA3.1 using Lipofectamine 2000. The full-length human isoform $695 \mathrm{APP}_{\text {Swe }}$ plasmid, generated by Dr. D. Selkoe (Young-Pearse et al., 2007), was obtained from Addgene (plasmid 30145). Following transfection, culture medium was replaced with $5 \mathrm{~mL}$ complete medium containing $10 \mu \mathrm{M}$ RA per $100 \mathrm{~mm}$ dish and grown for an additional $24 \mathrm{~h}$ to condition the medium. This CM collected from vector-expressing cells (CM-vector) and $\mathrm{APP}_{\mathrm{Swe}^{-}}$ expressing cells $\left(\mathrm{CM}-\mathrm{APP}_{\mathrm{Swe}}\right)$ was cleared of cells and cellular debris by centrifugation at $300 \times g$ at $4^{\circ} \mathrm{C}$ for $10 \mathrm{~min}$ and either used immediately or stored at $-80^{\circ} \mathrm{C}$. Storage at $-80^{\circ} \mathrm{C}$ does not alter the $\mathrm{A} \beta$ concentration in $\mathrm{CM}$ based on measurements using a human $A \beta_{1-42}$ ELISA or by $A \beta$ immunoblot profile. Two separate batches each of CM-vector and CM-APP Swe $_{\text {were collected from }}$ successive passages of cells $(250 \mathrm{~mL}$ total per collection from 50 culture plates) for use in these studies. The consistency in $A \beta$ concentration and $A \beta$ immunoblot profile was confirmed between CM batches using $A \beta_{1-42}$ ELISA to measure $A \beta_{1-42}$ concentration and $A \beta$ immunoprecipitation from $C M$ to assess the amount and apparent molecular masses of the $A \beta$ peptides recovered.

\section{Immunoprecipitation and Neutralization of Conditioned Medium}

In some experiments, $A \beta$ peptides were immunoprecipitated from $\mathrm{CM}$-vector and $\mathrm{CM}-\mathrm{APP}_{\text {Swe }}$. $\mathrm{CM}$ was first pre-cleared with $15 \mu \mathrm{L} / \mathrm{mL}$ of washed Protein G Sepharose for $1 \mathrm{~h}$ at $4^{\circ} \mathrm{C}$, then Protein-G Sepharose and non-specifically bound proteins were removed from $\mathrm{CM}$ by centrifugation at $2500 \times \mathrm{g}$ for $5 \mathrm{~min}$. Cleared CM supernatant was incubated with $5 \mu \mathrm{g} / \mathrm{mL}$ of either negative control anti-HA antibody, anti- $\mathrm{A} \beta[1-16]$ or anti-A $\beta[22-35]$ for $1 \mathrm{~h}$ at $4^{\circ} \mathrm{C}$. Washed Protein-G Sepharose $(15 \mu \mathrm{L} / \mathrm{mL})$ was then added to samples and mixed by rotation for $24 \mathrm{~h}$ at $4^{\circ} \mathrm{C}$. Protein-G Sepharose with bound proteins were collected by centrifugation and washed three times with lysis buffer to remove non-specifically bound proteins. Proteins were eluted by incubation for $10 \mathrm{~min}$ at $55^{\circ} \mathrm{C}$ with $\mathrm{A} \beta$ Laemmli sample buffer ( $2 \%$ SDS, $40 \%$ glycerol, $200 \mathrm{mM}$ Tris- $\mathrm{HCl}$, $\mathrm{pH} 6.8,0.04 \%$ bromophenol blue and $2 \% \beta$-mercaptoethanol), then separated on $12 \%$ SDS-PAGE gels and transferred to polyvinylidene difluoride (PVDF) membranes. Membranes were blocked in $8 \%$ non-fat dry milk in wash buffer (phosphatebuffered saline (PBS) with $0.15 \%$ Triton X-100) for $1 \mathrm{~h}$, then incubated overnight at $4^{\circ} \mathrm{C}$ with anti- $\mathrm{A} \beta[1-16]$ antibody (1:1000). After washing, membranes were incubated for $1 \mathrm{~h}$ in wash buffer containing $8 \%$ milk and peroxidase-conjugated goat anti-mouse IgG secondary antibody. Immunoreactive proteins on membranes were detected by chemiluminescence using a Chemidoc Imaging System (BioRad). Membranes were stripped for $20 \mathrm{~min}$ at $55^{\circ} \mathrm{C}$ followed by $5 \mathrm{~min}$ at room temperature in stripping buffer (62.5 mM Tris-HCl, pH 6.7, 2\% SDS, $0.78 \%$ 2 -mercaptoethanol), and then washed five times for $30 \mathrm{~min}$ in wash buffer before being re-probed with anti- $\mathrm{A} \beta[22-35]$ antibody (1:1000).

In experiments where $A \beta$ peptides were neutralized in $\mathrm{CM}$-vector and $\mathrm{CM}-\mathrm{APP}_{\text {Swe }}, \mathrm{CM}$ was incubated with $5 \mu \mathrm{g} / \mathrm{mL}$ of either negative control anti-HA antibody, anti-A $\beta[1-16]$ antibody or anti- $\mathrm{A} \beta[22-35]$ antibody for $24 \mathrm{~h}$ at $4^{\circ} \mathrm{C}$. This medium was then used to treat SY5Y-CHT cells that had been grown in complete medium containing $10 \mu \mathrm{M}$ RA for 3 days for a period of $24 \mathrm{~h}$ at $37^{\circ} \mathrm{C}$.

\section{$A \beta_{1-42}$ ELISA}

The amount of human $A \beta_{1-42}$ released by cells was measured in $\mathrm{CM}$-vector and $\mathrm{CM}-\mathrm{APP}_{\mathrm{Swe}}$ at $24 \mathrm{~h}$ following transfection using the human $A \beta_{1-42}$ ELISA kit (Invitrogen), according to the manufacturer's protocols. In some experiments, $\mathrm{CM}$ was incubated for an additional $24 \mathrm{~h}$ at $4^{\circ} \mathrm{C}$ with either anti-HA, anti$A \beta[1-16]$ or anti- $A \beta[22-35]$ antibody, then $A \beta_{1-42}$ content was measured.

\section{$\left[{ }^{3} \mathrm{H}\right]$ Choline Uptake Assay}

Choline uptake activity was evaluated in SY5Y-CHT cells grown for $24 \mathrm{~h}$ in either CM-vector or CM-APP ${ }_{\text {Swe }}$ that had been pre-incubated for $24 \mathrm{~h}$ with either anti-HA, anti-A $\beta[1-16]$ or anti-A $\beta[22-35]$ antibody. Monolayers of cells were rinsed with warm Krebs-Ringer-HEPES (KRH) buffer (mM: NaCl, 124; $\mathrm{KCl}, 5 ; \mathrm{MgSO}_{4}, 1.3 ; \mathrm{CaCl}_{2}, 1.5$; glucose, 10; HEPES-NaOH, 20; $\mathrm{pH}$ 7.4), then incubated in $\mathrm{KRH}$ at $37^{\circ} \mathrm{C}$ for $15 \mathrm{~min}$. This 
buffer was aspirated from cells and choline uptake initiated by the addition of $\mathrm{KRH}$ buffer containing $0.5 \mu \mathrm{M}\left[{ }^{3} \mathrm{H}\right]$ choline $(0.5 \mathrm{Ci} / \mathrm{mmol})$ either with or without $1 \mu \mathrm{M} \mathrm{HC}-3$. Uptake was stopped after 5 min by placing cells on ice and washing with ice-cold KRH. Cells were solubilized in $0.1 \mathrm{M} \mathrm{NaOH}$, then aliquots taken for tritium quantification by liquid scintillation counting and protein measurement.

\section{Cell Surface Protein Biotinylation Assay}

SY5Y-CHT cells plated on $100 \mathrm{~mm}$ dishes were grown for $24 \mathrm{~h}$ in either CM-vector and CM-APP ${ }_{\text {Swe }}$ that was immunodepleted by $24 \mathrm{~h}$ treatment with either anti-HA, anti-A $\beta[1-16]$ or anti-A $\beta$ [22-35] antibody. Cells were then washed twice with cold HBSS and placed on ice under cold HBSS to stop protein trafficking. Plasma membrane proteins were biotinylated on ice by incubating with $1 \mathrm{mg} / \mathrm{ml}$ sulfo-NHS-SS-biotin in HBSS for $1 \mathrm{~h}$. Unbound biotin was quenched by washing and incubating cells in cold $100 \mathrm{mM}$ glycine in HBSS. After two further washes with HBSS, cells were lysed on ice for $45 \mathrm{~min}$ in 1\% Triton X-100 lysis buffer. Neutravidin beads were incubated with cell lysates for $1 \mathrm{~h}$ at $4^{\circ} \mathrm{C}$ with gentle mixing to bind biotin-labeled proteins to allow their separation from the non-biotinylated proteins. Beads were then washed with lysis buffer three times and bound proteins were eluted by incubation for $10 \mathrm{~min}$ at $55^{\circ} \mathrm{C}$ with Laemmli sample buffer. Aliquots of biotinylated proteins and total cell lysates were separated on $10 \%$ SDS-PAGE gels and transferred to PVDF membranes. Membranes were blocked in $8 \%$ non-fat dry milk in wash buffer for $1 \mathrm{~h}$, and then incubated overnight with either anti-CHT (1:3000), anti-actin (1:3000), or anti-calnexin (1:1000) antibody in wash buffer with $8 \%$ non-fat milk. After washing, membranes were incubated for $1 \mathrm{~h}$ with either peroxidase-conjugated goat anti-rabbit IgG $(1: 10,000)$ or peroxidase-conjugated goat anti-mouse IgG $(1: 10,000)$ secondary antibody in wash buffer containing $8 \%$ milk, and washed again. Immunoreactive proteins were detected by chemiluminescence using a Chemidoc Imaging System (BioRad). Immunopositive bands were quantified by densitometry.

\section{Confocal Imaging}

Digital images of fixed cells were acquired with a Zeiss LSM510-Meta laser-scanning confocal microscope using a $63 \times$ magnification oil-immersion objective and magnified three times. Untransfected SY5Y-CHT cells plated on $35 \mathrm{~mm}$ dishes were grown for $24 \mathrm{~h}$ in $\mathrm{CM}$ collected from either vectorexpressing or $\mathrm{APP}_{\text {Swe }}$-expressing SY5Y-CHT cells. Immediately prior to cell treatment, CM was incubated for $24 \mathrm{~h}$ with either anti-HA, anti-A $\beta[1-16]$ or anti-A $\beta[22-35]$ antibody. Cells were then washed twice in warm HBSS and formaldehyde-fixed. Fixed cells were incubated first with anti-CHT (1:1000) or anti-LAMP1 (1:200) primary antibodies, then incubated with secondary antibodies rabbit AlexaFluor 647 (1:1000), to label CHT, and mouse AlexaFluor 488 (1:1000), to label LAMP1. Images were then acquired using $488 \mathrm{~nm}$ excitation and 505-530 nm emission wavelengths for LAMP1 and $647 \mathrm{~nm}$ excitation and $650 \mathrm{~nm}$ emission using a long pass filter for CHT. Co-localization analysis was performed on confocal images using Imaris software version 7.7.0 with the Imaris Co-localization module (Bitplane) to examine the co-localization of the brightest $2 \%$ of pixels in each channel, as described previously (Lorenzen et al., 2010; Cuddy et al., 2012).

\section{Data Analysis}

Data are presented as the mean \pm SEM with $n$ values representing the number of independent experiments performed on separate populations of cells; each $n$ value was obtained from the average of multiple sample replicates in each experiment. Replicate experiments were performed on cells cultured in successive passages as much as possible to minimize interexperiment variability, and intra-experiment variability between replicate samples was minimal. GraphPad Prism 5 was used for data analysis. Statistical significance was determined by paired Student's $t$-test, or between groups using repeated measures one-way analysis of variance (ANOVA) with Tukey's post hoc multiple comparison test or by two-way ANOVA, as appropriate.

\section{RESULTS}

\section{Soluble A $\beta$ Peptides Are Present in Medium Conditioned by SY5Y-CHT Cells Expressing APP $_{\text {Swe }}$}

The purpose of the present study was to investigate the effect of endogenously produced $\mathrm{A} \beta$ peptides on CHT function. To this end, we measured CHT activity and trafficking in untransfected SY5Y-CHT cells treated with Conditioned Media (CM) derived from SY5Y-CHT cells that transiently expressed either empty vector or $\mathrm{APP}_{\text {Swe }}\left(\mathrm{CM}\right.$-vector and $\mathrm{CM}-\mathrm{APP}_{\mathrm{Swe}}$, respectively). Therefore, we determined the amount and apparent molecular masses of soluble $\mathrm{A} \beta$ peptides present in $\mathrm{CM}$-vector and $\mathrm{CM}-\mathrm{APP}_{\text {Swe }} \mathrm{A} \beta$ peptides were recovered from $\mathrm{CM}$-vector and $\mathrm{CM}-\mathrm{APP}_{\mathrm{Swe}}$ by immunoprecipitation using either anti-HA antibody as a negative control, anti-A $\beta$ antibody directed at amino acids $1-16$ at the $\mathrm{N}$-terminus of $\mathrm{A} \beta$ (anti- $\mathrm{A} \beta[1-16]$ antibody) or anti- $\mathrm{A} \beta$ antibody directed at amino acids $22-35$ in the mid-region of $A \beta$ (anti-A $\beta[22-35]$ antibody). Figure 1A shows a representative immunoblot that was probed for $A \beta$ peptides using anti-A $\beta[1-16]$ antibody (top panel), then stripped and re-probed for $A \beta$ peptides using anti-A $\beta[22-35]$ antibody (bottom panel). No $A \beta$ peptides were immunoprecipitated from $\mathrm{CM}$-vector or $\mathrm{CM}-\mathrm{APP}_{\mathrm{Swe}}$ with the anti-HA antibody, whereas strong $\mathrm{A} \beta$ immunoreactive bands with masses of approximately $4-\mathrm{kDa}$ were recovered from $\mathrm{CM}-\mathrm{APP}_{\text {Swe }}$ immunoprecipitated with either anti-A $\beta[1-16]$ or anti-A $\beta[22-35]$ antibody (Figure 1A). Faint immunoreactive $\mathrm{A} \beta$ bands with masses of about $4-\mathrm{kDa}$ were also recovered by immunoprecipitation from CM-vector with either the anti-A $\beta[1-16]$ or the anti-A $\beta[22-35]$ antibody (Figure 1A). Immunoreactive $A \beta$ bands with higher molecular masses of approximately $8-\mathrm{kDa}$ and $12-\mathrm{kDa}$ were recovered from $\mathrm{CM}$-vector and $\mathrm{CM}-\mathrm{APP}_{\text {Swe }}$ immunoprecipitated with the anti$A \beta[22-35]$ antibody coupled with probing immunoblots with anti-A $\beta[22-35]$ (Figure 1A, lower panel). Faint immuoreactive 

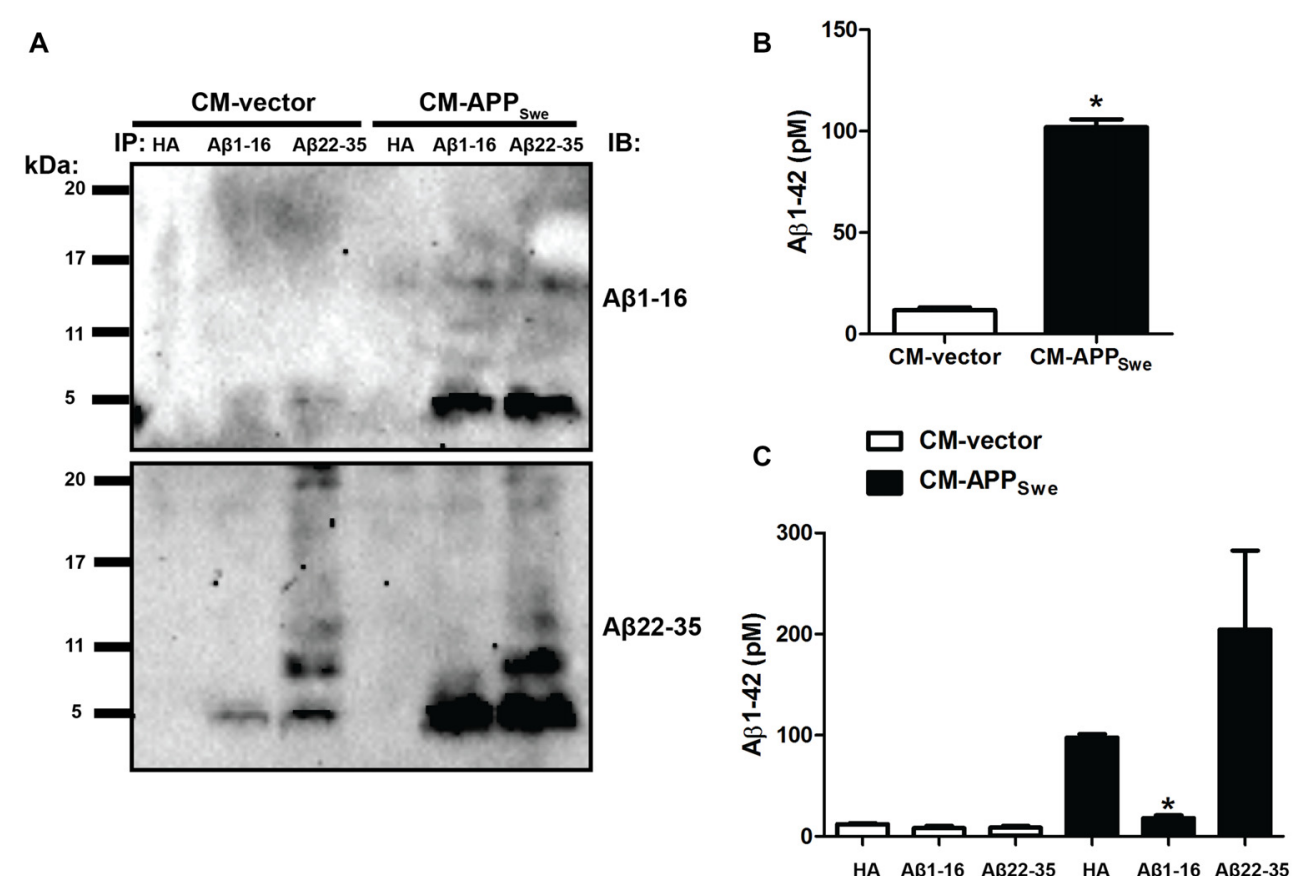

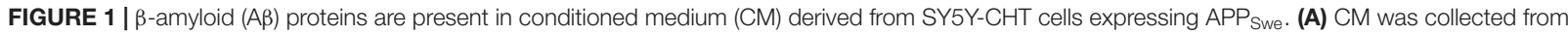

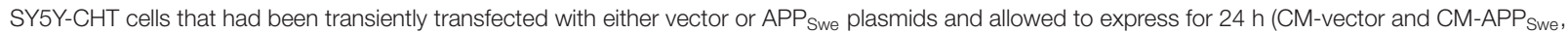
respectively). $A \beta$ was immunoprecipitated from $C M$-vector and $C M-A P P_{\text {swe }}$ using $A \beta$ antibody directed at amino acids $1-16$ of $A \beta$ (anti-A $\beta[1-16]$ ) or $A \beta$ antibody directed at amino acids 22-35 of A (anti-A 3 [22-35]) and Protein G Sepharose. Proteins were solubilized, separated by SDS-PAGE and transferred to polyvinylidene difluoride (PVDF) membranes. Membranes were probed with anti-A $\beta[1-16]$ (top panel) and anti-A $\beta[22-35]$ (lower panel). Representative immunoblots show A $\beta$ proteins present in $\mathrm{CM}$-vector and CM-APP Swe. $_{\text {CM-vector and CM-APP }}$ we were incubated with anti-HA antibody and Protein G Sepharose as a negative control (lanes 1 and 4). The immunoblots shown are representative of data obtained from three independent experiments. (B) Human A $\beta_{1-42}$ concentration in $\mathrm{CM}$-vector and

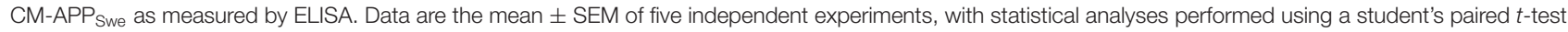
$\left({ }^{*} p \leq 0.05\right)$. (C) CM-vector and CM-APP swe were incubated with either $\mathrm{HA}$, anti-A $\beta[1-16]$ or anti-A $\beta[22-35]$ for $24 \mathrm{~h}$ and $\mathrm{A} \beta_{1-42}$ concentration was measured by

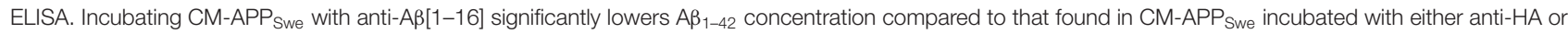
anti-A $[22-35]$ antibody. Data are the mean \pm SEM of five independent experiments, with statistical analyses performed using a repeated-measures one-way analysis of variance (ANOVA) with Tukey's post hoc multiple comparisons test $\left({ }^{*} p \leq 0.05\right)$

$\mathrm{A} \beta$ peptide bands with masses of approximately $16-\mathrm{kDa}$ were recovered from $\mathrm{CM}-\mathrm{APP}_{\text {Swe }}$ immunoprecipitated with either anti-A $\beta[1-16]$ or anti-A $\beta[22-35]$ antibody coupled with immunoblots probed with anti-A $\beta[1-16]$ antibody (Figure 1A, top panel). We next measured the concentration of $\mathrm{A} \beta_{1-42}$ in $\mathrm{CM}$-vector and $\mathrm{CM}-\mathrm{APP} \mathrm{Swe}_{\text {we }}$ using a human $\mathrm{A} \beta_{1-42}$ ELISA. As expected, the amount of $A \beta_{1-42}$ present in CM$\mathrm{APP}_{\text {Swe }}$ is significantly greater than that present in CM-vector $\left(11.7 \pm 1.3\right.$ and $101.9 \pm 3.9 \mathrm{pM} \mathrm{A} \beta_{1-42}$ for $\mathrm{CM}$-vector and $\mathrm{CM}-\mathrm{APP}_{\text {Swe }}$, respectively; $p \leq 0.05$; Figure 1B).

It has been demonstrated previously that $\mathrm{N}$-terminal $\mathrm{A} \beta$ antibodies can neutralize soluble synaptotoxic forms of $A \beta$ and inhibit adverse effects of $\mathrm{A} \beta$ in an epitope-specific manner (Buttini et al., 2005; Shankar et al., 2008; Jin et al., 2011; Zago et al., 2012). Both anti-A $\beta[1-16]$, an N-terminaldirected antibody, and anti-A $\beta$ [22-35], a mid-region directed antibody, effectively recovered $\mathrm{A} \beta$ peptides from $\mathrm{CM}-\mathrm{APP}_{\text {Swe }}$ by immunoprecipitation (Figure 1A). We next compared the ability of anti-A $\beta[1-16]$ and anti-A $\beta[22-35]$ antibodies to neutralize $\mathrm{A} \beta_{1-42}$ peptides present in $\mathrm{CM}-\mathrm{APP}_{\text {Swe }}$. To determine this, $\mathrm{CM}$-vector and $\mathrm{CM}-\mathrm{APP}_{\text {Swe }}$ were incubated for $24 \mathrm{~h}$ with either anti-HA, anti-A $\beta[1-16]$ or anti-A $\beta$ [22-35] antibody, then $A \beta_{1-42}$ concentrations in antibody-treated media were measured using a human $A \beta_{1-42}$ ELISA that recognizes the $\mathrm{N}$-terminus and C-terminus of $\mathrm{A} \beta_{1-42}$. As shown in Figure 1C, incubating $\mathrm{CM}-\mathrm{APP}_{\text {Swe }}$ for $24 \mathrm{~h}$ with anti-A $\beta[1-16]$ antibody significantly reduces $A \beta_{1-42}$ concentration in comparison to that found in $C M-A P P_{\text {Swe }}$ incubated for $24 \mathrm{~h}$ with either anti-HA or anti-A $\beta[22-35]$ antibody $(97.8 \pm 2.5,18.2 \pm 2.8$ and $204.5 \pm 78 \mathrm{pM} \mathrm{A} \beta_{1-42}$ for $\mathrm{CM}-\mathrm{APP}_{\text {Swe }}$ incubated with anti$\mathrm{HA}$, anti-A $\beta[1-16]$ or anti-A $\beta[22-35]$ antibody, respectively; $\left.{ }^{*} p \leq 0.05\right)$. While the anti-A $\beta[22-35]$ antibody bound to and could immunoprecipitate $\mathrm{A} \beta$ peptides from $\mathrm{CM}-\mathrm{APP} \mathrm{P}_{\text {Swe }}$ (Figure 1A), the $\mathrm{A} \beta_{1-42}$ concentration was not decreased by this antibody possibly because it does not bind to either the $\mathrm{N}$-terminal or $\mathrm{C}$-terminal amino acids of $\mathrm{A} \beta_{1-42}$ that are detected in the ELISA. While not statistically significant, the mean $A \beta_{1-42}$ concentration was higher in $C M-A P P_{\text {Swe }}$ incubated with the anti-A $\beta[22-35]$ antibody compared to $C M-A P P_{\text {Swe }}$ incubated with the anti-HA antibody. $\mathrm{A} \beta_{1-42}$ levels were not measurably changed in $\mathrm{CM}$-vector incubated with either anti$\mathrm{HA}$, anti-A $\beta[1-16]$ or anti-A $\beta[22-35]$ antibody (12.1 \pm 0.8 , 
$8.0 \pm 2.3$ and $8.7 \pm 1.8 \mathrm{pM} \mathrm{A} \beta_{1-42}$, respectively; $p \leq 0.05$ Figure 1C).

$\mathrm{CM}$-vector and CM-APP $\mathrm{Awe}_{\text {wed }}$ user cell treatments in this study were collected from successive passages of SY5Y-CHT cells transiently expressing either vector or $\mathrm{APP}_{\text {Swe }}$. The data above represent $\mathrm{CM}$-vector and $\mathrm{CM}-\mathrm{APP}_{\text {Swe }}$ collected from a single passage of SY5Y-CHT cells. Similar A $\beta$ concentrations and $\mathrm{A} \beta$ immunoblot profiles between $\mathrm{CM}$-vector and $\mathrm{CM}-\mathrm{APP} \mathrm{P}_{\text {Swe }}$ collected from successive cell passages were confirmed by $\mathrm{A} \beta_{1-42}$ ELISA to measure $A \beta_{1-42}$ concentration in the medium and immunoprecipitation of $A \beta$ to assess the amount and molecular masses of the recovered $A \beta$ peptides.

\section{$A \beta$-mediated Decrease in High-Affinity Choline Uptake by CHT Is Attenuated by A $\beta$ N-terminal Antibody}

The N-terminal directed anti-A $\beta[1-16]$ and mid-region directed anti-A $\beta[22-35]$ antibodies both effectively bind $A \beta$ in $C M-$ $\mathrm{APP}_{\text {Swe }}$ at different epitopes (Figure 1A). The purpose of the next experiment was to compare the effect of neutralizing $A \beta$ in $\mathrm{CM}-\mathrm{APP}_{\text {Swe }}$ with either anti-A $\beta[1-16]$ or anti-A $\beta[22-35]$ antibody on high-affinity choline uptake in SY5Y-CHT cells. To accomplish this, CM-vector was incubated with anti-HA antibody and $\mathrm{CM}-\mathrm{APP}_{\text {Swe }}$ was incubated with either anti$H A$, anti-A $\beta[1-16]$ or anti-A $\beta[22-35]$ antibody for $24 \mathrm{~h}$. SY5Y-CHT cells were then incubated with the antibody-treated $\mathrm{CM}$-vector or $\mathrm{CM}-\mathrm{APP}_{\text {Swe }}$, and $\left[{ }^{3} \mathrm{H}\right]$ choline uptake activity was measured. Choline uptake activity is significantly decreased in SY5Y-CHT cells treated with $\mathrm{CM}-\mathrm{APP}_{\text {Swe }}$ containing anti-HA antibody when compared to cells treated with CM-vector containing anti-HA antibody ( $p \leq 0.05$; Figure 2A). Interestingly, this significant decrease in high-affinity choline uptake activity was attenuated by incubation of $\mathrm{CM}-\mathrm{APP}_{\mathrm{Swe}}$ with anti-A $\beta[1-16]$ antibody, but not with anti-A $\beta[22-35]$ antibody (Figure 2A; $p \leq 0.05$ ). High-affinity choline uptake activity in SY5Y-CHT cells treated with CM-vector did not differ statistically from that measured in cells treated with $\mathrm{CM}-\mathrm{APP}_{\text {Swe }}$ containing anti-A $\beta[1-16]$ antibody. Total CHT protein levels were equivalent across the treatment groups (Figure 2B).

\section{A $\beta \mathrm{N}$-terminal Antibody Attenuates A $\beta$-mediated Loss of CHT Cell Surface Proteins}

Since the anti-A $\beta[1-16]$ antibody neutralizes soluble $A \beta$ peptides and prevents the decrease in high-affinity choline uptake seen in SY5Y-CHT cells treated with CM-APP ${ }_{\text {Swe }}$, we predicted that binding of anti-A $\beta[1-16]$ antibody to $A \beta$ would similarly protect against $\mathrm{A} \beta$-mediated loss of $\mathrm{CHT}$ cell surface expression. Thus, we performed cell surface protein biotinylation experiments using SY5Y-CHT cells treated for $24 \mathrm{~h}$ with CM-vector that had been incubated with anti-HA antibody or with CM-APP $\mathrm{Swe}_{\mathrm{S}}$ that had been incubated with either anti-HA, anti-A $\beta[1-16]$ or anti-A $\beta[22-35]$ antibody for $24 \mathrm{~h}$. Plasma membrane proteins were then biotinylated using membrane impermeable sulfoNHS-biotin at $4^{\circ} \mathrm{C}$. Representative immunoblots in Figure 3A
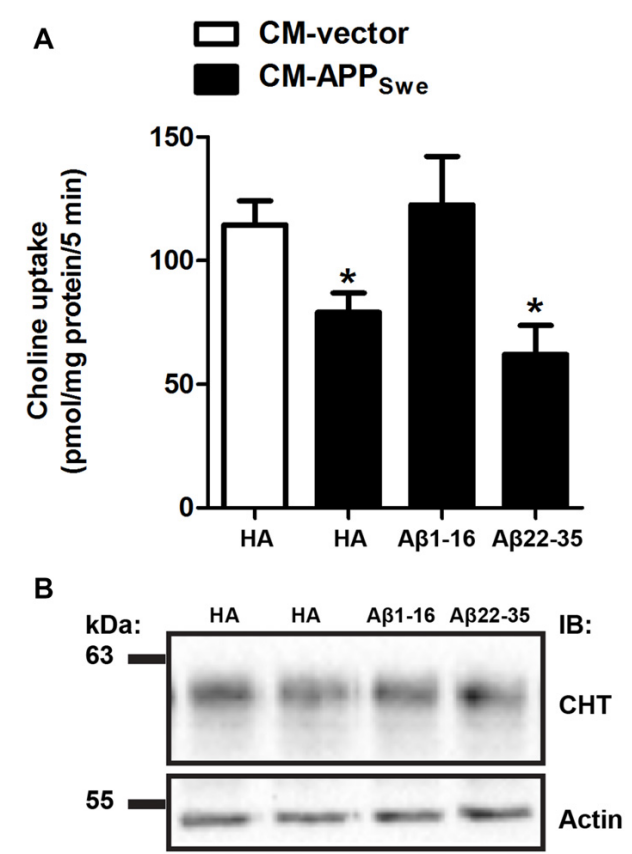

FIGURE 2 | N-terminal $A \beta$ antibody attenuates $A \beta$-mediated inhibition of $\left[{ }^{3} \mathrm{H}\right]$-choline uptake activity by choline transporter $(\mathrm{CHT})$. (A) CM was collected from SY5Y-CHT cells that had been transiently expressing either vector or APP $_{\text {swe }}$ plasmid DNA for $24 \mathrm{~h}$ (CM-vector and CM-APP swe, respectively). $\mathrm{CM}$-vector and CM-APP swe were incubated with either anti-HA, anti-A $\beta[1-16]$ or anti-A $\beta[22-35]$ antibody for $24 \mathrm{~h}$, added to SY5Y-CHT cells for $24 \mathrm{~h}$, then choline uptake was assayed. CHT activity was significantly reduced in cells

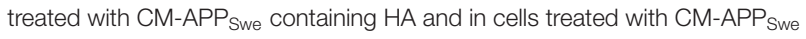
containing anti-A $\beta[22-35]$ when compared to cells treated with $C M$-vector or

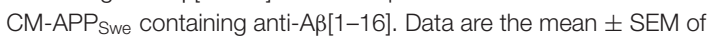
five independent experiments, with statistical analyses performed using a repeated-measures one-way ANOVA with Tukey's post hoc multiple comparisons test $\left({ }^{*} p \leq 0.05\right)$. (B) Representative immunoblots show steady-state total $\mathrm{CHT}$ and actin protein levels in total cell lysates from a representative choline uptake experiment.

show the cell surface levels of (biotinylated) CHT and calnexin proteins and the total amount of CHT, calnexin and actin proteins in cell lysates. Quantitative analysis of cell surface CHT protein immunoblots (top panel) reveals that $\mathrm{CHT}$ cell surface levels are significantly lower in SY5Y-CHT cells treated with $\mathrm{CM}-\mathrm{APP}_{\text {Swe }}$ containing either anti-HA or anti$\mathrm{A} \beta[22-35]$ antibody, but not in SY5Y-CHT cells treated with $\mathrm{CM}-\mathrm{APP}_{\text {Swe }}$ containing anti-A $\beta[1-16]$ antibody when compared to CM-vector treated SY5Y-CHT cells (Figure 3B; $p \leq 0.05$ ). Total CHT protein levels are equal between cells treated with either $\mathrm{CM}$-vector or $\mathrm{CM}-\mathrm{APP}_{\text {Swe }}$ incubated with either anti-HA, anti-A $\beta[1-16]$ or anti-A $\beta[22-35]$ antibody (middle panel). CHT cell surface levels did not differ between SY5Y-CHT cells treated with CM-vector and cells treated with $\mathrm{CM}-\mathrm{APP}_{\text {Swe }}$ containing anti-A $\beta[1-16]$ (Figure 3A, lanes 1 and 3 , respectively). The absence of calnexin immunoreactivity in biotinylated cell surface fractions and its presence in total cell lysate fractions confirmed the isolation of cell surface proteins. 


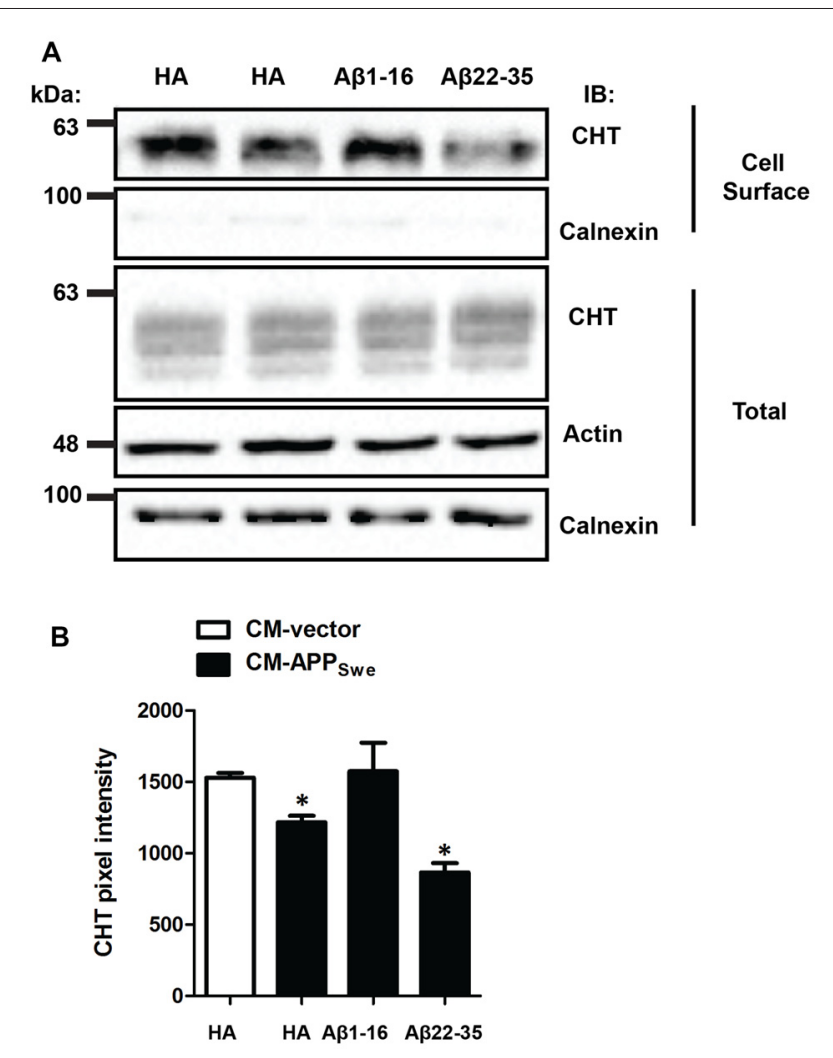

FIGURE 3 | N-terminal $A \beta$ antibody attenuates $A \beta$-mediated inhibition of $C H T$ plasma membrane levels. (A) CM was collected from SY5Y-CHT cells that had been transiently expressing either vector or APP $_{\text {Swe }}$ plasmid DNA for $24 \mathrm{~h}$ (CM-vector and CM-APP swe $_{\text {, }}$ respectively). CM-vector and CM-APP swe were incubated with either anti-HA, anti-A $\beta[1-16]$ or anti-A $\beta[22-35]$ antibody for $24 \mathrm{~h}$ and then added to SY5Y-CHT cells for $24 \mathrm{~h}$. Cells were then washed and placed on ice, and then plasma membrane proteins were biotinylated.

Biotinylated proteins were captured using NeutrAvidin agarose, then proteins were solubilized and separated by SDS-PAGE. PVDF membranes were processed by immunoblotting with antibodies recognizing $\mathrm{CHT}$, actin and calnexin. Representative immunoblots show steady-state $\mathrm{CHT}$, actin and calnexin protein levels in total cell lysates (3 lower panels). The top panels illustrate cell surface (biotinylated) $\mathrm{CHT}$ and calnexin proteins. The immunoblots shown are representative of data obtained from five independent experiments. (B) Analysis of cell surface $\mathrm{CHT}$ protein bands by densitometry reveals that the level of $\mathrm{CHT}$ protein at the cell surface is significantly reduced in cells treated with $\mathrm{CM}-\mathrm{APP}_{\text {Swe }}$ containing $\mathrm{HA}$ and in cells treated with

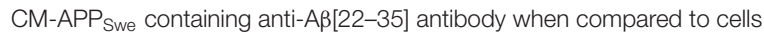

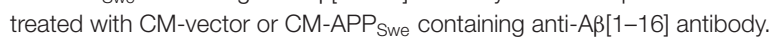
Data are the mean \pm SEM of five independent experiments, with statistical analyses performed using a repeated-measures one-way ANOVA with Tukey's post hoc multiple comparisons test $\left({ }^{*} p \leq 0.05\right)$.

\section{A $\beta$-mediated Decrease in CHT Co-Localization with Early Endosome EEA1 Is Attenuated by $\mathrm{N}$-terminal $A \beta$ Antibody}

Plasma membrane CHT levels are maintained by constitutive recycling of $\mathrm{CHT}$ proteins between endocytic compartments and the cell surface, thereby regulating choline uptake activity. CHT proteins internalize rapidly from the plasma membrane to early endosomes by a clathrin-mediated process, thus we investigated whether $A \beta$ present in $\mathrm{CM}-\mathrm{APP}_{\text {Swe }}$ alters $\mathrm{CHT}$ localization to early endosomes. To this end, we used confocal microscopy to visualize the co-localization of $\mathrm{CHT}$ and early endosome maker EEA1 in SY5Y-CHT cells treated with either CM-vector containing anti-HA antibody or $\mathrm{CM}-\mathrm{APP}_{\text {Swe }}$ containing either anti-HA, anti-A $\beta[1-16]$ or anti-A $\beta[22-35]$ antibody. To assess the extent of co-localization between CHT and EEA1, we used a quantitative approach using Imaris software (Bitplane) to set threshold fluorescence intensities that filter the brightest $2 \%$ of pixels of $\mathrm{CHT}$ (shown in green) that also fall within the brightest $2 \%$ of pixels of EEA1 (shown in red). This analysis is described further in Hutcheon et al. (2000) and Lorenzen et al. (2010). The co-localized pixels are identified in a separate co-localization channel and shown as white in the right overlay panels of Figure 4A. As shown in Figure 4B, analysis of the quantified pixels revealed that $\mathrm{CHT}$ co-localizes significantly less with EEA1 in cells treated with CM-APP incubated with either anti-HA or anti-A $\beta$ [22-35] antibody $(31.3 \pm 1.0 \%$ and $28.9 \pm 1.0 \%$, respectively) compared to cells treated with either $\mathrm{CM}$-vector or $\mathrm{CM}-\mathrm{APP}_{\text {Swe }}$ containing with anti-A $\beta[1-16]$ antibody $(35.6 \pm 1.0 \%$ and $41.5 \pm 1.1 \%$, respectively). Unexpectedly, $\mathrm{CHT}$ co-localizes significantly more with EEA1 in cells treated with $\mathrm{CM}-\mathrm{APP}_{\text {Swe }}$ containing anti$\mathrm{A} \beta[1-16]$ compared to cells treated to $\mathrm{CM}$-vector treated cells. The reason for this is unknown, but could be due to low physiological levels of $A \beta$ present in $C M$-vector and not present in $\mathrm{CM}-\mathrm{APP}_{\text {Swe }}$ containing anti-A $\beta[1-16]$, thereby regulating $\mathrm{CHT}$ recycling between early endosomes and the cell surface.

\section{A $\beta$-mediated Decrease in CHT Co-Localization with Lysosome Marker LAMP-1 Is Attenuated by N-terminal A $\beta$ Antibody}

CHT proteins internalize to early endosomes from the plasma membrane and either recycle back to the cell surface or move through late endosomes to lysosomes for degradation (Cuddy et al., 2012). Our results reveal that $A \beta$ causes a significant decrease in CHT activity and cell surface expression that corresponds with a significant loss of CHT proteins from early endosomes. Thus, we hypothesize that the $A \beta$-mediated loss of $\mathrm{CHT}$ proteins from early endosomes, and the corresponding decrease in CHT cell surface expression and activity, could be related to an increased movement of $\mathrm{CHT}$ to lysosomes for degradation. We next used confocal microscopy to visualize the co-localization of CHT and lysosome marker LAMP-1 in SY5Y-CHT cells treated with either CM-vector containing anti-HA antibody or $\mathrm{CM}-\mathrm{APP}_{\text {Swe }}$ containing either anti-HA, anti-A $\beta[1-16]$ or anti-A $\beta[22-35]$ antibody. To assess the extent of co-localization between CHT and LAMP-1, we used the quantitative approach described above to set threshold fluorescence intensities that filter the brightest $2 \%$ of pixels of $\mathrm{CHT}$ (shown in green) that also fall within the brightest $2 \%$ of pixels of LAMP-1 (shown in red). The co-localized pixels are identified in a separate co-localization channel and shown as white in the right overlay panels of Figure 5A. As shown in Figure $5 \mathrm{~B}$, analysis of the quantified pixels revealed that $\mathrm{CHT}$ 


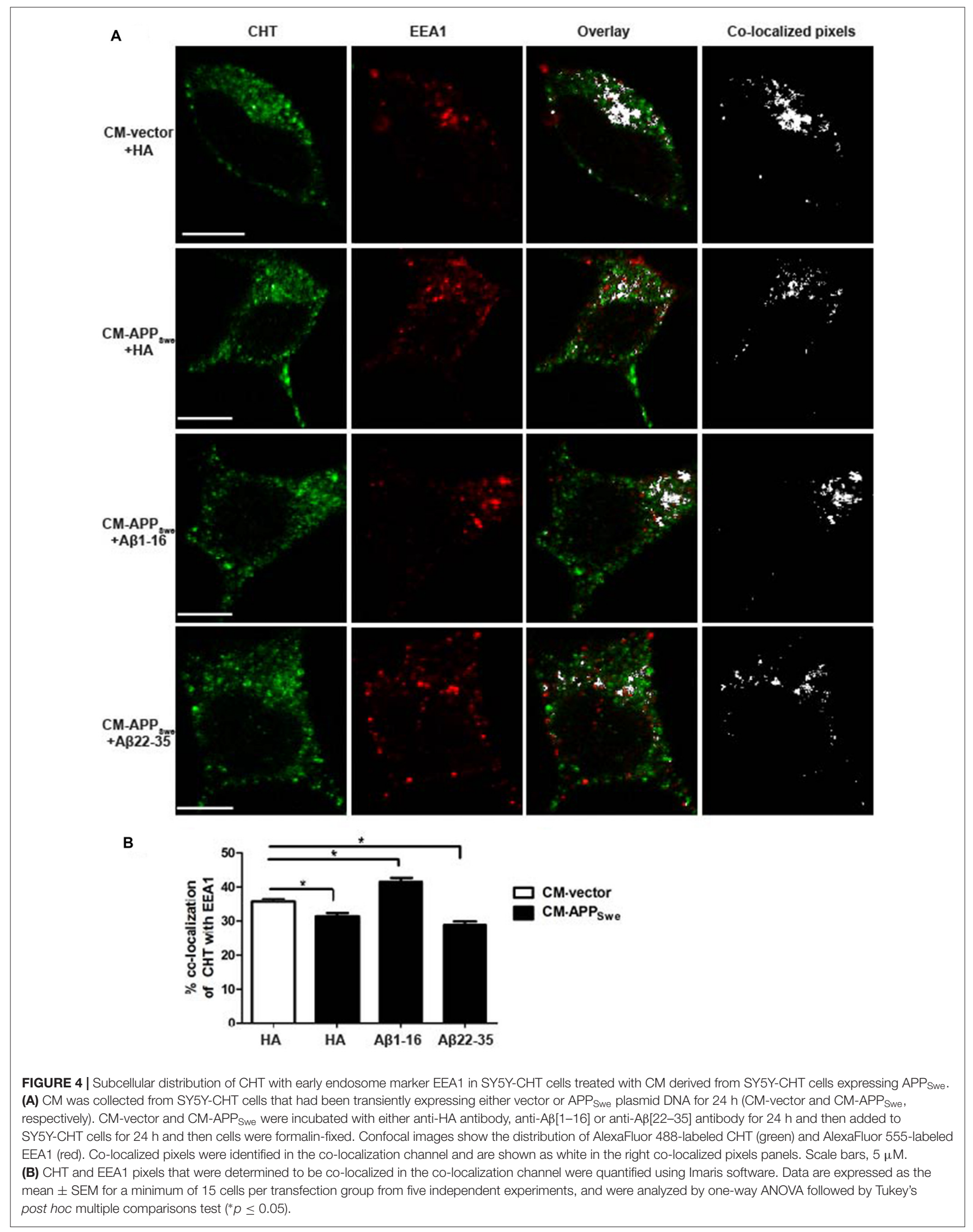




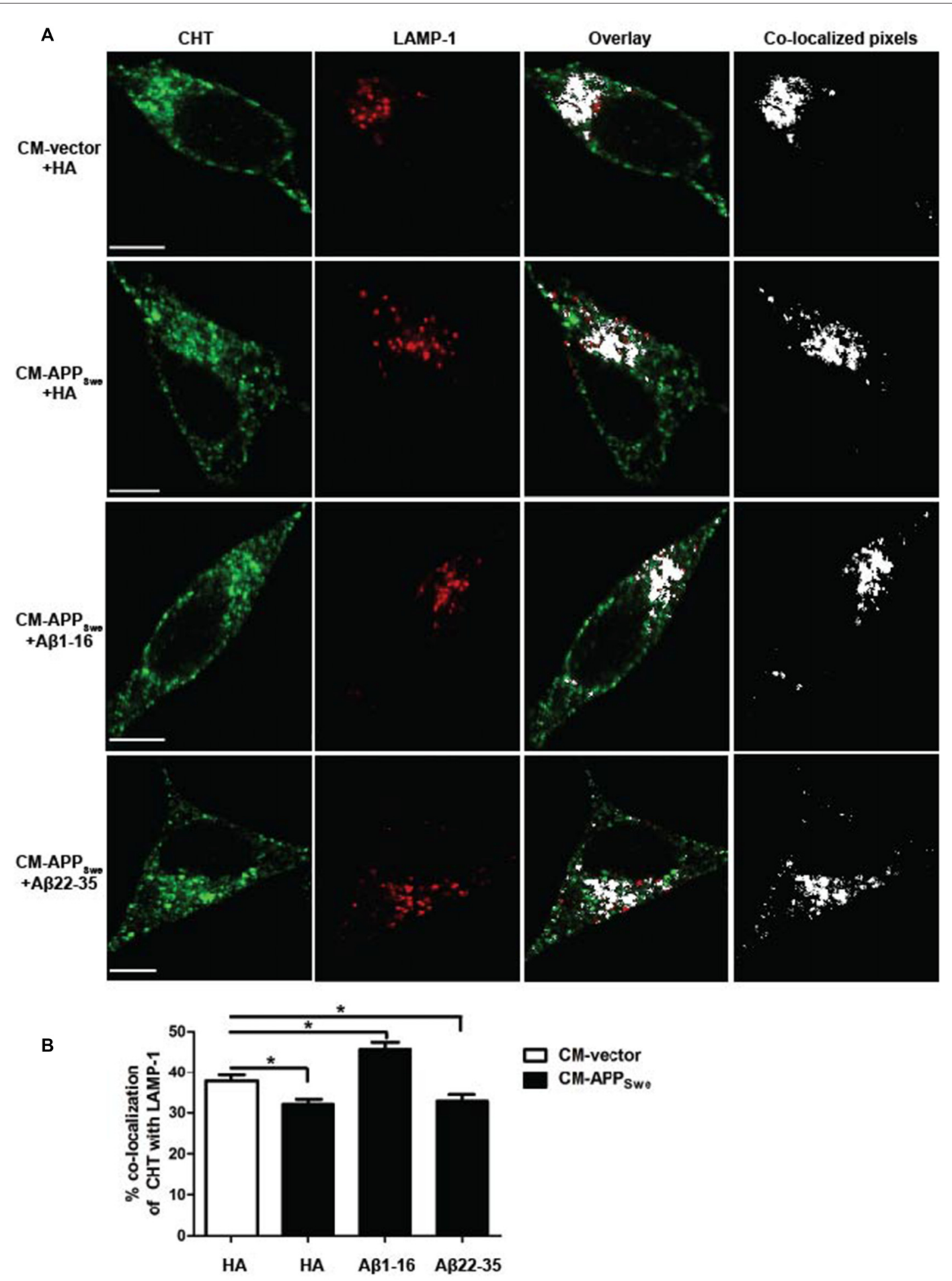

FIGURE 5 | Subcellular distribution of CHT with lysosome marker LAMP-1 in SY5Y-CHT cells treated with CM derived from SY5Y-CHT cells expressing APPSwe. (A) CM was collected from SY5Y-CHT cells that had been transiently expressing either vector or APP swe plasmid DNA for $24 \mathrm{~h}$ (CM-vector and CM-APPswe,

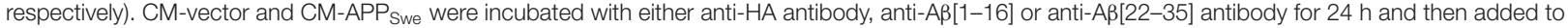
SY5Y-CHT cells for $24 \mathrm{~h}$ and then cells were formalin-fixed. Confocal images show the distribution of AlexaFluor 647-labeled CHT (green) and AlexaFluor 488-labeled LAMP-1 (red). Co-localized pixels were identified in the co-localization channel and are shown as white in the right co-localized pixels panels. Scale bars, $5 \mu$ M. (B) $\mathrm{CHT}$ and LAMP-1 pixels that were determined to be co-localized in the co-localization channel were quantified using Imaris software. Data are expressed as the mean \pm SEM for a minimum of 18 cells per transfection group from four independent experiments, and were analyzed by one-way ANOVA followed by Tukey's post hoc multiple comparisons test $\left({ }^{*} p \leq 0.05\right)$. 
co-localizes significantly less with LAMP-1 in cells treated with $\mathrm{CM}-\mathrm{APP}_{\text {Swe }}$ incubated with either anti-HA or anti-A $\beta[22-35]$ antibody ( $32 \pm 1.2 \%$ and $33 \pm 1.6 \%$, respectively) compared to cells treated with either $\mathrm{CM}$-vector or $\mathrm{CM}-\mathrm{APP}_{\text {Swe }}$ containing anti- $A \beta[1-16]$ antibody ( $38 \pm 1.4 \%$ and $45 \pm 1.6 \%$, respectively). Consistent with our observation that $\mathrm{CHT}$ co-localizes more with EEA1 in cells treated with $\mathrm{CM}-\mathrm{APP}{ }_{\text {Swe }}$ containing anti-A $\beta[1-16]$ compared to cells treated to $\mathrm{CM}$-vector treated cells, $\mathrm{CHT}$ also co-localizes significantly more with LAMP- 1 in cells treated with $\mathrm{CM}-\mathrm{APP} \mathrm{Swe}_{\text {we }}$ containing anti-A $\beta[1-16]$ compared to cells treated to CM-vector treated cells.

\section{Lysosome Inhibitor Bafilomycin A1 Prevents A $\beta$-mediated Decrease in CHT Co-Localization with LAMP-1}

$\mathrm{A} \beta$ peptides present in $\mathrm{CM}-\mathrm{APP}_{\text {Swe }}$ decrease the amount of $\mathrm{CHT}$ localizing to both early endosomes and lysosomes (Figures 4 , 5 , respectively). To investigate whether the $A \beta$-mediated loss of CHT proteins from early endosomes and lysosomes is related to increased CHT degradation by the lysosome, we blocked proteolytic activity of the lysosome pharmacologically using $\mathrm{BafA}_{1}$ (which blocks acidification of the lysosome), and measured CHT co-localization with LAMP-1 by confocal microscopy. In this experiment, SY5Y-CHT cells were treated with either $\mathrm{CM}$-vector or $\mathrm{CM}-\mathrm{APP}_{\text {Swe }}$ containing either vehicle or BafA $A_{1}$ and the extent of co-localization between CHT and LAMP-1 was assessed using the quantitative approach described above. Co-localization between CHT and LAMP-1 was observed in cells treated with either $\mathrm{CM}$-vector or $\mathrm{CM}-\mathrm{APP}_{\text {Swe }}$ containing either vehicle or BafA $\mathrm{B}_{1}$ (Figure 6A). Co-localized pixels of CHT and LAMP-1 appear white in the overlay panels and co-localized pixels panels of these images. As shown in Figure 6B, and consistent with our findings above (Figure 5), analysis of the quantified pixels revealed that CHT co-localizes significantly less with LAMP-1 in cells treated with CM-APP ${ }_{\text {Swe }}$ containing vehicle compared to cells treated with $\mathrm{CM}$-vector containing vehicle ( $41.6 \pm 1.5 \%$ and $48.1 \pm 1.4 \%$, respectively). Importantly, treatment of cells with CM-APP ${ }_{\text {Swe }}$ containing $\mathrm{BafA}_{1}$ attenuated the effect of $\mathrm{CM}-\mathrm{APP}_{\mathrm{Swe}}$, with co-localization of $\mathrm{CHT}$ with LAMP-1 not differing significantly between these treatment groups ( $47.4 \pm 1.7 \%$ and $47.1 \pm 1.9 \%$, respectively).

\section{Lysosome Inhibitor Bafilomycin $A_{1}$ Prevents A $\beta$-mediated Decrease in CHT Cell Surface Expression, but Not CHT Activity}

We investigated whether $A \beta$ inhibits $C H T$ function by increasing lysosomal degradation of $\mathrm{CHT}$ proteins by blocking proteolytic activity of lysosomes using the inhibitor $\mathrm{BafA}_{1}$, then measuring CHT cell surface expression and activity using cell surface protein biotinylation and choline uptake assays, respectively.

To determine the effect of lysosome inhibition on CHT cell surface expression, SY5Y-CHT cells were treated with either $\mathrm{CM}$-vector or $\mathrm{CM}^{-\mathrm{APP}_{\text {Swe }}}$ containing either vehicle or $\mathrm{BafA}_{1}$ for $24 \mathrm{~h}$. Plasma membrane proteins were then biotinylated using membrane impermeable sulfo-NHS-biotin at $4^{\circ} \mathrm{C}$. Representative immunoblots in Figure 7A show the level of cell surface (biotinylated) $\mathrm{CHT}$ and calnexin proteins and the amount of total CHT, calnexin and actin protein. Total CHT protein levels (middle panel) are equal between cells treated with either $\mathrm{CM}$-vector or $\mathrm{CM}-\mathrm{APP}_{\text {Swe }}$ containing vehicle, while total CHT protein levels are substantially increased in cells treated with $\mathrm{CM}$ containing $\mathrm{BafA}_{1}$ compared to cells treated with $\mathrm{CM}$ containing vehicle. Quantitative analysis was carried out on immunoblots of biotinylated cell surface CHT protein levels (top panel). Statistical analysis by two-way ANOVA reveals no interaction between media treatment and drug $\left(\mathrm{BafA}_{1}\right)$ treatment of cells $(P=0.46)$, but there is a statistically significant difference related to $\mathrm{BafA}_{1}$ treatment of cells $(P=0.0018)$ with this lysosome inhibitor attenuating the decrease in cell surface $\mathrm{CHT}$ protein levels observed in cells treated with $\mathrm{CM}-\mathrm{APP}_{\text {Swe }}$ containing vehicle. In SY5Y-CHT cells treated with CM-APP ${ }_{S w e}$ containing vehicle, cell surface CHT protein levels are decreased by $28 \%$ when compared to cells treated with CM-vector containing vehicle (Figure 7B); this is comparable to the statistically significant $22 \%$ decrease in CHT cell surface levels for the same treatment groups shown in Figure 3. BafA $\mathrm{A}_{1}$ treatment attenuated the effect of $\mathrm{CM}-\mathrm{APP}_{\mathrm{Sw}}$, with $\mathrm{CHT}$ cell surface levels being the same for cells treated with $\mathrm{CM}$-vector and $\mathrm{CM}-\mathrm{APP}_{\text {Swe. The }}$ absence of calnexin immunoreactivity in biotinlyated cell surface fractions and presence in total cell lysate fractions confirmed the isolation of cell surface proteins.

Since $B a f A_{1}$ prevents the $A \beta$-mediated decrease in $C H T$ cell surface expression in SY5Y-CHT cells treated with CM-APP ${ }_{\text {Swe }}$, we predicted that $B a f A_{1}$ would also block an $A \beta$-mediated decrease in high-affinity choline uptake activity. To test this, cells were treated with either $\mathrm{CM}$-vector or $\mathrm{CM}-\mathrm{APP}_{\text {Swe }}$ containing either vehicle or $\mathrm{BafA}_{1}$ for $24 \mathrm{~h}$, then $\left[{ }^{3} \mathrm{H}\right]$ choline uptake activity was measured (Figure 7C). Statistical analysis by two-way ANOVA revealed no interaction between media treatment and drug $\left(\mathrm{BafA}_{1}\right)$ treatment $(P=0.06)$, and while there was no difference related to $\mathrm{BafA}_{1}$ treatment $(P=0.18)$, a significant difference was found for media treatment $(P=0.0005)$. In SY5Y-CHT cells treated with $\mathrm{CM}-\mathrm{APP}_{\text {Swe }}$ containing vehicle, choline uptake activity is decreased by $37 \%$ when compared to cells treated with CM-vector containing vehicle (Figure 7C); this is comparable to the statistically significant $31 \%$ decrease in choline uptake activity for the same treatment groups shown in Figure 2. Interestingly, high-affinity choline uptake activity was not increased in SY5Y-CHT cells treated with CM-APP ${ }_{\text {Swe }}$ containing $\mathrm{BafA}_{1}$ when compared to vehicle. Figure $7 \mathrm{D}$ is a representative experiment showing that total sample CHT and actin protein levels were equivalent across the treatment groups.

\section{DISCUSSION}

We investigated the effect of $\mathrm{A} \beta$ peptides present in $\mathrm{CM}$ collected from $\mathrm{APP}_{\text {Swe }}$-expressing cells $\left(\mathrm{CM}-\mathrm{APP}_{\text {Swe }}\right)$ on $\mathrm{CHT}$ trafficking and activity. APP containing the Swedish mutation that causes familial $\mathrm{AD}$ undergoes high-efficiency amyloidogenic cleavage, increasing A $\beta$ production by 10 -fold (Haass et al., 1995; Thinakaran et al., 1996). We found recently that, when compared 


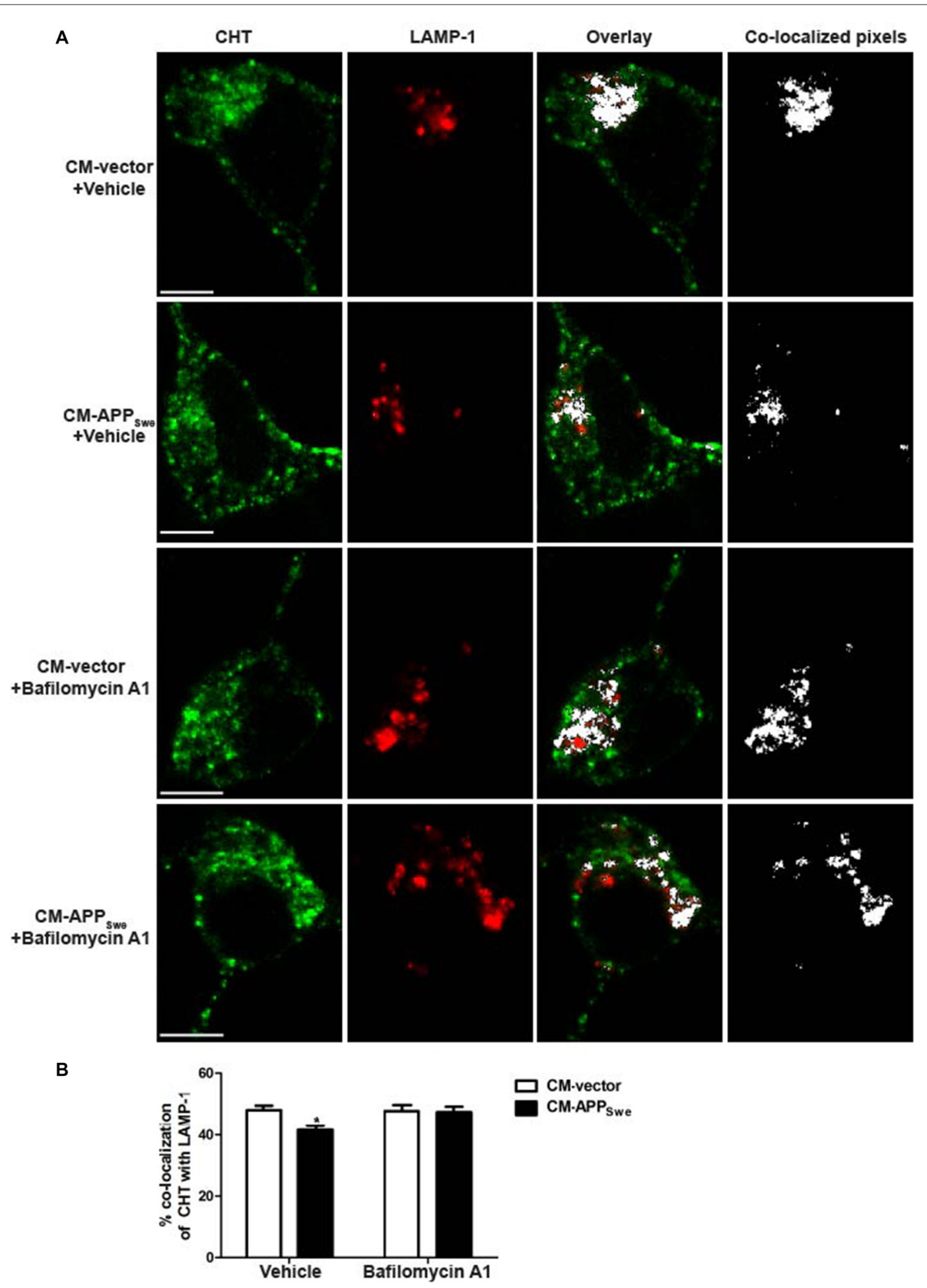

FIGURE 6 | Subcellular distribution of CHT with lysosome marker LAMP-1 in SY5Y-CHT cells treated with CM derived from SY5Y-CHT cells expressing APP swe

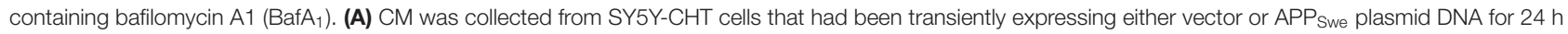
(CM-vector and CM-APP swe, respectively). CM-vector and CM-APP swe containing either vehicle (DMSO) or $20 \mathrm{nM}$ BafA 1 were added to SY5Y-CHT cells for $24 \mathrm{~h}$ and then cells were formalin-fixed. Confocal images show the distribution of AlexaFluor 647-labeled CHT (green) and AlexaFluor 488-labeled LAMP-1 (red). Co-localized pixels were identified in the co-localization channel and are shown as white in the right co-localized pixels panels. Scale bars, $5 \mu \mathrm{M}$. (B) $\mathrm{CHT}$ and LAMP-1 pixels that were determined to be co-localized in the co-localization channel were quantified using Imaris software. Data are expressed as the mean \pm SEM for a minimum of 15 cells per transfection group from four independent experiments, and were analyzed by two-way ANOVA followed by Tukey's post hoc multiple comparisons test $\left({ }^{*} p \leq 0.05\right)$. 

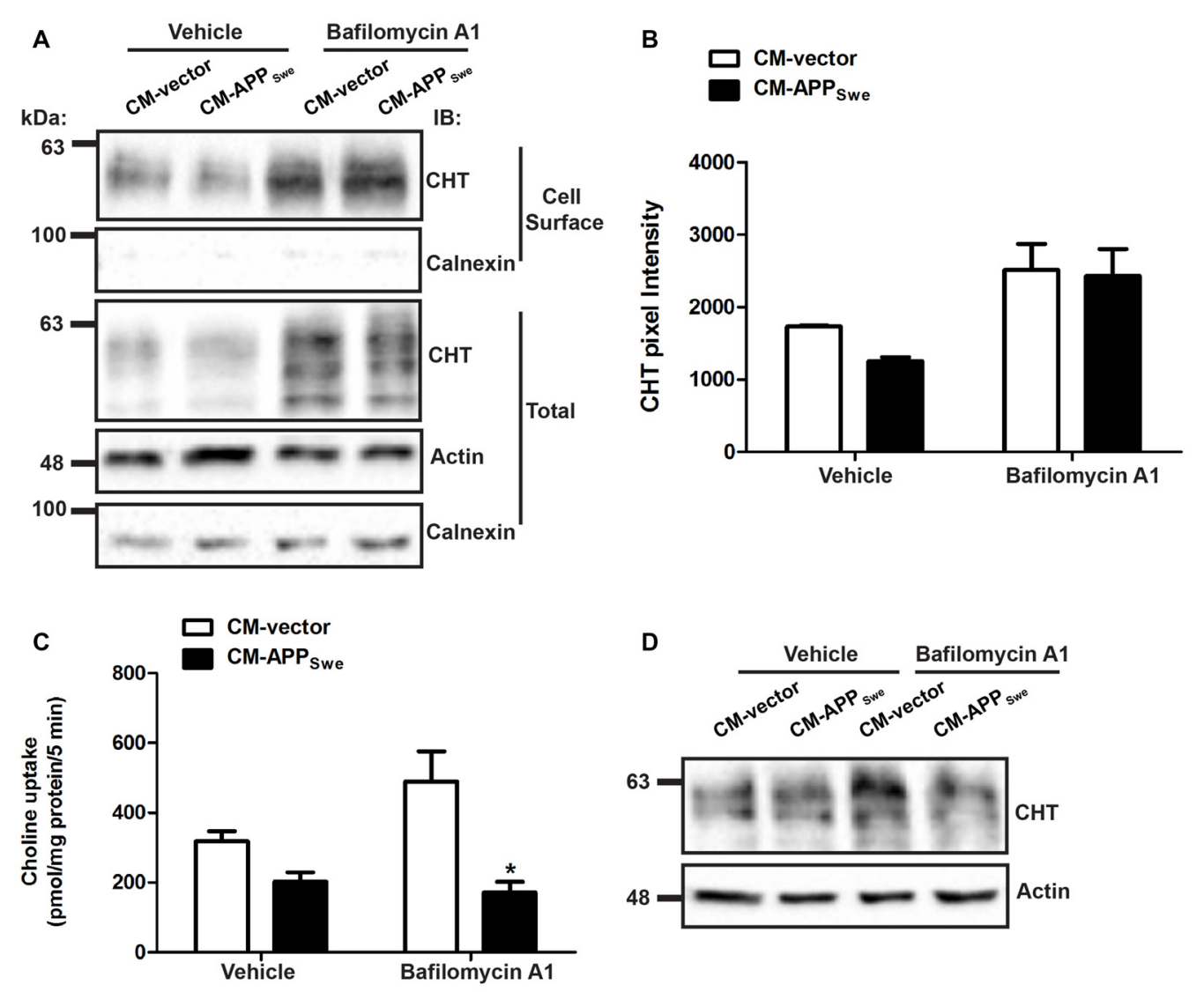

FIGURE 7 | BafA 1 blocks an A $\beta$-mediated decrease in $\mathrm{CHT}$ cell surface expression but not $\mathrm{CHT}$ activity. (A) CM was collected from SY5Y-CHT cells that had been

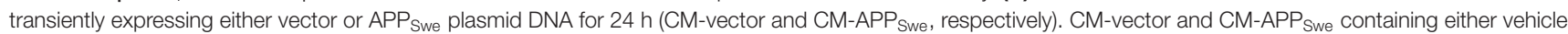
(DMSO) or $20 \mathrm{nM} \mathrm{BafA}_{1}$ were added to SY5Y-CHT cells for $24 \mathrm{~h}$. Cells were then washed and placed on ice, and then plasma membrane proteins were biotinylated. Representative immunoblots show steady-state $\mathrm{CHT}$, actin and calnexin protein levels in total cell lysates (3 lower panels). The top panels illustrate cell surface (biotinylated) $\mathrm{CHT}$ and calnexin proteins. The immunoblots shown are representative of data obtained from five independent experiments. (B) Analysis of cell surface $\mathrm{CHT}$ protein bands by densitometry reveals that the level of $\mathrm{CHT}$ protein at the cell surface is reduced in cells treated with $\mathrm{CM}_{\mathrm{APP}} \mathrm{AP}_{\text {swe }}$ containing vehicle compared to cells treated with $\mathrm{CM}$-vector containing vehicle. No differences in the level of CHT protein at the cell surface were observed in cells treated with CM-vector containing Baf $A_{1}$ compared to cells treated with $\mathrm{CM}_{-}-\mathrm{APP}_{\text {swe }}$ containing Baf $\mathrm{A}_{1}$. Data are the mean \pm SEM of five independent experiments, with statistical analyses performed using a two-way ANOVA with Bonferroni post hoc multiple comparisons test ( $\left.{ }^{*} p \leq 0.05\right)$. (C) CM-vector and CM-APPswe containing either vehicle or $20 \mathrm{nM}$ BafA $_{1}$ were added to SY5Y-CHT cells for $24 \mathrm{~h}$, and then choline uptake was assayed. CHT activity was reduced in cells treated with CM-APP swe $_{\text {Containing }}$ vehicle compared to cells treated with $\mathrm{CM}$-vector containing vehicle. $\mathrm{CHT}$ activity was significantly reduced in cells treated with $\mathrm{CM}_{\mathrm{A}} \mathrm{APP}_{\mathrm{Swe}} \mathrm{Containing} \mathrm{BafA}_{1}$ when compared to cells treated with $\mathrm{CM}$-vector containing BafA $\mathrm{A}_{1}$. Data are the mean $\pm \mathrm{SEM}$ of five independent experiments, with statistical analyses performed using a two-way ANOVA with Bonferroni post hoc multiple comparisons test ( $\left.{ }^{*} p \leq 0.05\right)$. (D) Representative immunoblots show steady-state total $\mathrm{CHT}$ and actin protein levels in total cell lysates from a representative choline uptake experiment.

to wild-type APP, expression of $\mathrm{APP}_{\text {Swe }}$ in neural cells decreases $\mathrm{CHT}$ function by a mechanism that was related to increased $\mathrm{APP}_{\text {Swe }}$ processing (Cuddy et al., 2015). We now make the novel observation that treatment of neural cells with CM-APP $\mathrm{Swe}_{\mathrm{S}}$ decreases CHT co-localization with the early endosome marker EEA1 and lysosome marker LAMP-1. Moreover, we found that the lysosome inhibitor $\mathrm{BafA}_{1}$ attenuates $\mathrm{A} \beta$-mediated decreases in CHT cell surface levels. However, lysosome inhibition did not block the effect of A $\beta$ on CHT activity. Finally, inhibition of CHT function by $A \beta$ peptides was blocked by an antibody directed at the $N$-terminal amino acids $1-16$ of $A \beta$ (anti-A $\beta[1-16]$ ), but not by an antibody directed at the mid-region amino acids $22-35$ of $\mathrm{A} \beta$ (anti-A $\beta[22-35])$.
$\mathrm{A} \beta$ peptides assemble into soluble oligomers, protofibrils and fibrils that accumulate in the brains of $\mathrm{AD}$ subjects. It was considered initially that fibrillar $A \beta$ was responsible for cholinergic dysfunction seen early in $\mathrm{AD}$, but cognitive impairment correlates better with the level of soluble $A \beta$ oligomers than with fibril deposition, suggesting that $A \beta$ oligomers are the more toxic $A \beta$ species (Shankar et al., 2008; Li et al., 2009). While soluble $A \beta$ peptides alter neuron function, $\mathrm{A} \beta$ preparations from different sources including synthetic and cell-derived $A \beta$ peptides can differ in toxicity and potency. For example, soluble A $\beta$ produced by mutant APP-expressing 7PA2 cells is 100 times more potent than synthetic $A \beta$ in producing errors in a cognitive function assay in rats 
(Reed et al., 2012). Synthetic preparations of soluble A $\beta$ can inhibit high-affinity choline uptake (Kar et al., 1998; Kristofiková et al., 2001; Parikh et al., 2014), thus we tested the effect of A $\beta$ peptides released from cells on $\mathrm{CHT}$ function. Our data reveal that low $\mathrm{pM}$ concentrations of soluble $\mathrm{A} \beta$ present in $\mathrm{CM}-\mathrm{APP}_{\text {Swe }}$ significantly inhibit choline uptake activity in SY5Y-CHT cells. These findings agree with previous reports that chronic and acute treatment with $\mathrm{A} \beta$ peptides in the $\mathrm{fM}$ to $\mu \mathrm{M}$ concentration range significantly inhibit choline uptake in both in vitro and in vivo models (Kar et al., 1998; Kristofikova et al., 2013; Parikh et al., 2014). Together, these data show that CHT proteins are highly sensitive to $A \beta$ peptides, suggesting that early changes in $A D$ brain that cause small shifts in $\mathrm{A} \beta$ generation could have a large impact on $\mathrm{CHT}$ activity and cholinergic transmission.

Little is known about the mechanism by which $A \beta$ peptides impair high-affinity choline uptake. We show that this $\mathrm{A} \beta$ mediated inhibition corresponds to a significant decrease in CHT cell surface levels in SY5Y-CHT cells and predicted that $A \beta$ promotes CHT internalization, which has also been observed for N-methyl-D aspartate (NMDA) and $\alpha$-amino-3-hydroxy-5methyl-4-isoxazole-propionic acid (AMPA) glutamate receptors (Hsieh et al., 2006; Dewachter et al., 2009). We found significantly decreased CHT localization in early endosomes and lysosomes in SY5Y-CHT cells treated for $24 \mathrm{~h}$ with CM$\mathrm{APP}_{\text {Swe }}$. Previous data reveal that $\mathrm{CHT}$ proteins internalize into early endosomes from the plasma membrane by a dynamindependent, clathrin-mediated mechanism with a $t_{1 / 2}$ of about 15 min (Ribeiro et al., 2005; Cuddy et al., 2012). CHT proteins then either recycle back to the plasma membrane, or move to late endosomes and lysosomes within about $30 \mathrm{~min}$ after internalization where they normally undergo degradation (Cuddy et al., 2012). Oxidative-nitrosative stress can result in enhanced ubiquitination of CHT proteins, with some transporters directed to proteosomal degradation (Cuddy et al., 2012). One explanation for our findings is that $A \beta$ increases $C H T$ protein internalization and movement to lysosomes where they are degraded, resulting in fewer CHT proteins at the cell surface, in early endosomes and in lysosomes at $24 \mathrm{~h}$. While total CHT protein levels in cells were unchanged, this is likely due to the relatively small proportion of the total cellular $\mathrm{CHT}$ proteins that are present at the plasma membrane and in the recycling pool that feeds CHT proteins to the cell surface. In both cultured cells and rat brain nerve endings, only $15 \%$ of total $\mathrm{CHT}$ proteins are contained within this recycling pool and at the cell surface, with the majority being found in other intracellular vesicular compartments (Ferguson et al., 2003; Ribeiro et al., 2005). Thus, an $\mathrm{A} \beta$-mediated decrease in the pool of CHT proteins present at the cell surface may not be detected when measuring total cellular CHT levels.

To investigate whether exposure of cells to CM-APP $\mathrm{Swe}_{\text {we }}$ containing $\mathrm{A} \beta$ peptides increases lysosomal degradation of CHT, we blocked proteolytic activity of lysosomes using $\mathrm{BafA}_{1}$ and measured the effect on subcellular localization and function of CHT. In support of our hypothesis that $A \beta$ increases lysosomal degradation of $\mathrm{CHT}, \mathrm{BafA}_{1}$ attenuated the $\mathrm{CM}-\mathrm{APP}_{\text {Swe }}$-mediated decrease in $\mathrm{CHT}$ proteins in lysosomes and also blocked the decrease in CHT cell surface levels.
Inhibition of lysosomal degradation of $\mathrm{CHT}$ by $\mathrm{BafA}_{1}$ was confirmed by an increase in total and cell surface $\mathrm{CHT}$ protein levels. The increase in cell surface levels of $\mathrm{CHT}$ protein in BafA1-treated cells grown in $\mathrm{CM}-\mathrm{APP}_{\text {Swe }}$ medium may be due to less CHT being degraded and actively recycling back to the plasma membrane. Interestingly, $\mathrm{BafA}_{1}$ treatment attenuated the effect of CM-APP Swe $_{\text {on }}$ CHT cell surface levels, but not on CHT activity. An explanation for this finding is that the conformational state of $\mathrm{CHT}$ required for solute binding or solute translocation may be altered by $A \beta$, thereby impairing the function of transporters that are retained at the cell surface. However, the underlying mechanisms for this are unknown. A direct interaction between $\mathrm{A} \beta$ and $\mathrm{CHT}$ has been reported, but the mechanistic impact of this interaction was not investigated (Bales et al., 2006). It is possible that $\mathrm{A} \beta$ interacts with $\mathrm{CHT}$ proteins at a solute recognition site and prevents solute binding, as has been observed for both the glutamate and glycine agonist recognition sites of the NMDA receptor (Cowburn et al., 1997). $\mathrm{A} \beta$ could also affect $\mathrm{CHT}$ function indirectly by its effects on the lipid bilayer. $A \beta$ oligomers bind principally to membrane lipids and secondarily interrupt the structure and function of several synaptic transmembrane transporters and channels. This mechanism is consistent with the effect of soluble $A \beta$ on glutamate uptake by isolated synaptosomes in vitro ( $\mathrm{Li}$ et al., 2009). We showed previously that CHT proteins are concentrated in lipid rafts and disrupting rafts significantly alters CHT activity and solute binding affinity (Cuddy et al., 2014). Moreover, disruption of lipid rafts enhances the $\mathrm{A} \beta$-mediated inhibition of CHT activity (Kristofikova et al., 2013). Together, these data indicate that lipid rafts maintain CHT in a functional conformation required for either solute binding or translocation and this may be altered by $\mathrm{A} \beta$.

To confirm that CHT inhibition in CM-APP Swe $_{\text {treated cells }}$ was due to $A \beta$ peptides and not to other proteolytic fragments of APP, we tested the effects of neutralizing $A \beta$ peptides in $\mathrm{CM}-\mathrm{APP}_{\text {Swe }}$ using anti-A $\beta$ antibodies. Several antibodies targeting different epitopes of $\mathrm{A} \beta$ have been developed, with some being evaluated clinically for the treatment of mild to moderate $\mathrm{AD}$. Most studies have focused on $\mathrm{N}$-terminal antibodies, based on results obtained from active immunization strategies using B-cell epitopes of $\mathrm{A} \beta$ located in the $\mathrm{N}$-terminus of the peptide (Schneeberger et al., 2009; Spencer and Masliah, 2014). Bapineuzumab, an N-terminal $A \beta$ antibody targeted at residues $1-5$ of $A \beta$ was the first immunotherapy in clinical trials, but showed only minimal cognitive benefits (Tayeb et al., 2013; Salloway et al., 2014). Solanezumab, a mid-region-directed A $\beta$ antibody recognizing residues $13-28$ of $A \beta$ showed a significant $33 \%$ reduction in rate of decline in patients with mild $\mathrm{AD}$ (Doody et al., 2014). In preclinical studies, $\mathrm{N}$-terminal $\mathrm{A} \beta$ antibodies can neutralize and block the deposition of toxic species of $A \beta$ peptides and show beneficial effects in various $\mathrm{AD}$ mouse models by preventing synaptic degeneration and reversing memory deficits in object recognition and Morris water maze (Dodart et al., 2002; Bard et al., 2003; Buttini et al., 2005). In the present study, we compared the effect of neutralizing $\mathrm{CM}-\mathrm{APP}_{\text {Swe }}$ with either $\mathrm{N}$-terminal $\mathrm{A} \beta$ antibody $6 \mathrm{E} 10$ that recognizes amino acids 1-16 (anti-A $\beta[1-16]$ ) or mid-region $A \beta$ antibody recognizing 
amino acids 22-35 (anti-A $\beta[22-35]$ ) on CHT function. Our data reveal that anti-A $\beta[1-16]$, but not anti-A $\beta$ [22-35], blocked inhibition of $\mathrm{CHT}$ function by $\mathrm{A} \beta$ present in $\mathrm{CM}-\mathrm{APP}_{\text {Swe }}$.

Our data suggest that the site at which $\mathrm{A} \beta$ impacts $\mathrm{CHT}$ function lies within the N-terminal amino acids $1-16$ of $\mathrm{A} \beta$ peptide. While this observation is in agreement with evidence showing a neuroprotective effect of $\mathrm{N}$-terminal $\mathrm{A} \beta$ antibodies, other studies have suggested that the mid-region of $A \beta$ is responsible for mediating $\mathrm{CHT}$ dysfunction. Structure-activity analysis shows that the non-aggregated synthetic $A \beta$ fragments $\mathrm{A} \beta_{1-42}, \mathrm{~A} \beta_{1-40}, \mathrm{~A} \beta_{1-28}$ and $\mathrm{A} \beta_{25-35}$ inhibit high-affinity choline uptake and $\mathrm{ACh}$ release from rat hippocampal slices similarly, suggesting that $A \beta$ peptide residues 25-28 are required for these effects (Kar et al., 1998). In a separate study, the anti$\mathrm{A} \beta$ antibody $\mathrm{m} 266$ that recognizes amino acids $13-28$ of $\mathrm{A} \beta$ restored hippocampal ACh release and high-affinity choline uptake and reduced impaired habituation learning in PDAPP mice, but the anti-A $\beta$ antibody 3D6 directed at amino acids 1-5 of $A \beta$ was without effect (Bales et al., 2006). The differences in these findings could be explained by differences in the mechanism by which low concentrations of naturallyproduced soluble $A \beta$ used in the present study inhibit $\mathrm{CHT}$ activity, compared to non-aggregated synthetic peptides of $A \beta$ or high concentrations of fibrillar $A \beta$ present in the brains of PDAPP mice. Moreover, anti-A $\beta$ antibodies display epitope specificities in binding and prevention of formation of distinct $A \beta$ species, which could differentially affect CHT function. For example, it has been proposed that the antiA $\beta$ m266 antibody may inhibit $A \beta$ fibril formation, but have no effect on A $\beta$ oligomerization (Legleiter et al., 2004). Interestingly, it was recently shown that 3D6, the murine form of $\mathrm{N}$-terminal $\mathrm{A} \beta$ antibody Bapineuzumab, binds to soluble assemblies of $A \beta_{1-42}$ and prevents functional consequences in hippocampal neurons including changes in glutamate AMPA receptor trafficking (Zago et al., 2012). We did not investigate whether differences exist in the ability of anti-A $\beta[1-16]$ and anti-A $\beta[22-35]$ to bind to or prevent the formation of different $\mathrm{A} \beta$ assemblies in $\mathrm{CM}-\mathrm{APP}_{\text {Swe }}$. However, anti$\mathrm{A} \beta[1-16]$ and anti-A $\beta[22-35]$ appear to immunoprecipitate different higher molecular weight $\mathrm{A} \beta$ species from $\mathrm{CM}-\mathrm{APP}_{\text {Swe }}$ with anti- $\mathrm{A} \beta[1-16]$ isolating higher molecular weight $16-\mathrm{kDa}$ $\mathrm{A} \beta$ species while anti- $\mathrm{A} \beta[22-35]$ isolated $8-\mathrm{kDa}$ and $12-\mathrm{kDa}$ A $\beta$-species.

\section{REFERENCES}

Auld, D. S., Kar, S., and Quirion, R. (1998). $\beta$-amyloid peptides as direct cholinergic neuromodulators: a missing link? Trends Neurosci. 21, 43-49. doi: 10.1016/S0166-2236(97)01144-2

Bales, K. R., Tzavara, E. T., Wu, S., Wade, M. R., Bymaster, F. P., Paul, S. M., et al. (2006). Cholinergic dysfunction in a mouse models of Alzheimer disase is reversed by an anti-A $\beta$ antibody. J. Clin. Invest. 116, 825-832. doi: $10.1172 /$ jci27120

Bard, F., Barbour, R., Cannon, C., Carretto, R., Fox, M., Games, D., et al. (2003). Epitope and isotype specificities of antibodies to $\beta$-amyloid peptide for protection against Alzheimer's disease-like neuropathology. Proc. Natl. Acad. Sci. U S A 100, 2023-2028. doi: 10.1073/pnas.0436 286100
In conclusion, we report novel observations regarding the regulation of $\mathrm{CHT}$ function by $\mathrm{A} \beta$. We reveal for the first time that naturally produced soluble forms of $A \beta$ increase lysosomal degradation of $\mathrm{CHT}$, but make the critical observation that while blocking this pathway does restore cell surface CHT protein levels it does not attenuate the effect of $\mathrm{A} \beta$ on $\mathrm{CHT}$ activity. This suggests that $A \beta$ may result in altered proteinprotein interactions or post-translational modification of CHT, thereby increasing its movement to the lysosome. It may also cause important effects on the conformational state of CHT required for choline uptake activity, either directly or indirectly through effects on the lipid bilayer. Moreover, we show that an N-terminal $A \beta$ antibody binds with soluble forms of $A \beta$ and attenuates the effect of $\mathrm{A} \beta$ on $\mathrm{CHT}$ activity and trafficking. Interestingly, a mid-region $A \beta$ antibody did not alter $A \beta$ effects on $\mathrm{CHT}$, indicating that a specific N-terminal $\mathrm{A} \beta$ epitope or conformation of soluble A $\beta$ may impair $\mathrm{CHT}$ activity. Together, our data suggest that therapeutic strategies that prevent $A \beta$ binding to CHT could be more effective in the treatment or prevention of $\mathrm{AD}$ than strategies designed to promote $\mathrm{CHT}$ cell surface expression.

\section{AUTHOR CONTRIBUTIONS}

LKC performed all experiments except for cell imaging, and CS performed cell imaging. LKC, CS and RJR designed the experiments and were involved in analysis and interpretations of data, and in drafting, revision and critical analysis of the manuscript. SHP was involved in analysis and interpretations of data, drafting, revision and critical analysis of the manuscript. All authors agree to be accountable for all aspects of the work and ensure that all questions related to accuracy or integrity of the article have been appropriately investigated and resolved, and give final approval for the version to be published.

\section{ACKNOWLEDGMENTS}

This research was supported by a grant to RJR from Canadian Institutes of Health Research (CIHR; grant \# FRN-115135). LKC is the recipient of a Queen Elizabeth II Graduate Scholarship in Science and Technology and a Doctoral Research Award from the Alzheimer Society of Canada.

Bard, F., Cannon, C., Barbour, R., Burke, R. L., Games, D., Grajeda, H., et al. (2000). Peripherally administered antibodies against amyloid $\beta$ peptide enter the central nervous system and reduce pathology in a mouse model of Alzheimer disease. Nat. Med. 6, 916-919. doi: 10.1038/78682

Black, S. A. G., and Rylett, R. J. (2012). Choline transporter CHT regulation and function in cholinergic neurons. Cent. Nerv. Syst. Agents Med. Chem. 12, 114-121. doi: 10.2174/187152412800792724

Buttini, M., Masliah, E., Barbour, R., Grajeda, H., Motter, R., Johnson-Wood, K., et al. (2005). $\beta$ amyloid immunotherapy prevents synaptic degeneration in a mouse model of Alzheimer's disease. J. Neurosci. 25, 9096-9101. doi: 10.1523/JNEUROSCI.1697-05.2005

Chen, X., Lin, R., Chang, L., Xu, S., Wei, X., Zhang, J., et al. (2013). Enhancement of long-term depression by soluble amyloid $\beta$ protein in rat hippocampus is mediated by metabotropic glutamate receptor and involves activation of 
p38MAPK, STEP and caspase-3. Neuroscience 253, 435-443. doi: 10.1016/j. neuroscience.2013.08.054

Cowburn, R. F., Wiehager, B., Trief, E., Li-Li, M., and Sundström, E. (1997). Effects of $\beta$-amyloid-(25-35) peptides on radioligand binding to excitatory amino acid receptors and voltage-dependent calcium channels: evidence for a selective affinity for the glutamate and glycine recognition sites of the NMDA receptor. Neurochem. Res. 22, 1437-1442. doi: 10.1023/A:1021942109490

Cuddy, L. K., Gordon, A. C., Black, S. A. G., Jaworski, E., Ferguson, S. S. G., and Rylett, R. J. (2012). Peroxynitrite donor SIN-1 alters high-affinity choline transporter activity by modifying its intracellular trafficking. J. Neurosci. 32, 5573-5584. doi: 10.1523/JNEUROSCI.5235-11.2012

Cuddy, L. K., Seah, C., Pasternak, S. H., and Rylett, R. J. (2015). Differential regulation of the high-affinity choline transporter by wild-type and Swedish mutant amyloid precursor protein. J. Neurochem. 134, 769-782. doi: $10.1111 /$ jnc. 13167

Cuddy, L. K., Winick-Ng, W., and Rylett, R. J. (2014). Regulation of the high-affinity choline transporter activity and trafficking by its association with cholesterol-rich lipid rafts. J. Neurochem. 128, 725-740. doi: 10.1111/jnc. 12490

DeMattos, R. B., Bales, K. R., Cummins, D. J., Dodart, J. C., Paul, S. M., and Holtzman, D. M. (2001). Peripheral anti-A $\beta$ antibody alters CNS and plasma A $\beta$ clearance and decreases brain A $\beta$ burden in a mouse model of Alzheimer's disease. Proc. Natl. Acad. Sci. U S A 98, 8850-8855. doi: 10.1073/pnas. 151261398

Dewachter, I., Filipkowski, R. K., Priller, C., Ris, L., Neyton, J., Croes, S., et al. (2009). Deregulation of NMDA-receptor function and down-stream signaling in APP[V717I] transgenic mice. Neurobiol. Aging 30, 241-256. doi: 10.1016/j. neurobiolaging.2007.06.011

Dodart, J. C., Bales, K. R., Gannon, K. S., Greene, S. J., DeMattos, R. B., Mathis, C., et al. (2002). Immunization reverses memory deficits without reducing brain A burden in Alzheimer's disease model. Nat. Neurosci. 5, 452-457. doi: 10.1038/nn842

Doody, R. S., Thomas, R. G., Farlow, M., Iwatsubo, T., Vellas, B., and Joffe, S. (2014). Phase 3 trials of solanezumab for mild-to-moderate Alzheimer's disease. N. Engl. J. Med. 370, 311-321. doi: 10.1056/NEJMoa1312889

Ferguson, S. M., Savchenko, V., Apparsundaram, S., Zwick, M., Wright, J., Heilman, C., et al. (2003). Vesicular localization and activity-dependent trafficking of presynaptic choline transporters. J. Neurosci. 23, 9697-9709.

Haass, C., Lemere, C. A., Capell, A., Citron, M., Seubert, P., Schenk, D., et al. (1995). The Swedish mutation causes early-onset alzheimer's disease by $\beta$ secretase cleavage within the secretory pathway. Nat. Med. 1, 1291-1296. doi: $10.1038 / \mathrm{nm} 1295-1291$

Haga, T., and Noda, H. (1973). Choline uptake systems of rat brain synaptosomes. Biochim. Biophys. Acta 291, 564-575. doi: 10.1016/0005-2736(73) 90508-7

Hsieh, H., Boehm, J., Sato, C., Iwatsubo, T., Tomita, T., Sisodia, S., et al. (2006). AMPAR removal underlies $A \beta$-induced synaptic depression and dendritic spine loss. Neuron 52, 831-843. doi: 10.1016/j.neuron.2006.10.035

Hutcheon, B., Brown, L. A., and Poulter, M. O. (2000). Digital analysis of light microscope immunofluorescence: high-resolution co-localization of synaptic proteins in cultured neurons. J. Neurosci. Methods 96, 1-9. doi: 10.1016/s01650270(99)00148-x

Jin, M., Shepardson, N., Yang, T., Chen, G., Walsh, D., and Selkoe, D. J. (2011). Soluble amyloid $\beta$-protein dimers isolated from Alzheimer cortex directly induce Tau hyperphosphorylation and neuritic degeneration. Proc. Natl. Acad. Sci. U S A 108, 5819-5824. doi: 10.1073/pnas.1017033108

Kar, S., Issa, A. M., Seto, D., Auld, D. S., Collier, B., and Quirion, R. (1998). Amyloid $\beta$-peptide inhibits high-affinity choline uptake and acetylcholine release in rat hippocampal slices. J. Neurochem. 70, 2179-2187. doi: 10.1046/j. 1471-4159.1998.70052179.x

Kristofikova, Z., Ripova, D., Hegnerova, K., Sirova, J., and Homola, J. (2013). Protein $\tau$-mediated effects on rat hippocampal choline transporters CHT1 and $\tau$-amyloid $\beta$ interactions. Neurochem. Res. 38, 1949-1959. doi: 10.1007/s11064013-1101-5

Kristofiková, Z., Tejkalova, H., and Klaschka, J. (2001). Amyloid $\beta$ peptide 1-40 and the function of rat hippocampal hemicholinium-3 sensitive choline carriers: effects of a proteolytic degradation in vitro. Neurochem. Res. 26, 203-212. doi: 10.1023/A:1010908315391
Kuhar, M. J., and Murrin, L. C. (1978). Sodium-dependent, high affinity choline uptake. J. Neurochem. 30, 15-21. doi: 10.1111/j.1471-4159.1978.tb07029.x

Legleiter, J., Czilli, D. L., Gitter, B., DeMattos, R. B., Holtzman, D. M., and Kowalewski, T. (2004). Effect of different anti-A $\beta$ antibodies on $A \beta$ fibrillogenesis as assessed by atomic force microscopy. J. Mol. Biol. 335, 997-1006. doi: 10.1016/j.jmb.2003.11.019

Li, S., Hong, S., Shepardson, N. E., Walsh, D. M., Shankar, G. M., and Selkoe, D. (2009). Soluble oligomers of amyloid $\beta$-protein facilitate hippocampal long-term depression by disrupting neuronal glutamate uptake. Neuron 62, 788-801. doi: 10.1016/j.neuron.2009.05.012

Lorenzen, A., Samosh, J., Vandewark, K., Anborgh, P. H., Seah, C., Magalhaes, A. C., et al. (2010). Rapid and direct transport of cell surface APP to the lysosome defines a novel selective pathway. Mol. Brain 3:11. doi: 10.1186/1756-6606-3-11

Miles, L. A., Crespi, G. A., Doughty, L., and Parker, M. W. (2013). Bapineuzumab captures the $\mathrm{N}$-terminus of the Alzheimer's disease amyloid- $\beta$ peptide in a helical conformation. Sci. Rep. 3:1302. doi: 10.1038/srep01302

Nitsch, R. M., Slack, B. E., Wurtman, R. J., and Growdon, J. H. (1992). Release of Alzheimer amyloid precursor derivatives stimulated by activation of muscarinic acetylcholine receptors. Science 258, 304-307. doi: 10.1126/science. 1411529

Okuda, T., and Haga, T. (2000). Functional characterization of the human high-affinity choline transporter. FEBS Lett. 484, 92-97. doi: 10.1016/s00145793(00)02134-7

Panza, F., Frisardi, V., Imbimbo, B. P., Seripa, D., Paris, F., Santamato, A. et al. (2011). Anti- $\beta$ amyloid immunotherapy for Alzheimer's disease: focus on bapineuzumab. Curr. Alzheimer Res. 8, 808-817. doi: 10.2174/156720511798192718

Parikh, V., Bernard, C. S., Naughton, S. X., and Yegla, B. (2014). Interactions between $\mathrm{A} \beta$ oligomers and presynaptic cholinergic signaling: age-dependent effects on attentional capacities. Behav. Brain Res. 274, 30-42. doi: 10.1016/j. bbr.2014.07.046

Pedersen, W. A., Kloczewiak, M. A., and Blusztajn, J. K. (1996). Amyloid $\beta$ protein reduces acetylcholine synthesis in a cell line derived from cholinergic neurons of the basal forebrain. Proc. Natl. Acad. Sci. U S A 93, 8068-8071. doi: 10.1073/pnas.93.15.8068

Pinthong, M., Black, S. A., Ribeiro, F. M., Pholpramool, C., Ferguson, S. S., and Rylett, R. J. (2008). Activity and subcellular trafficking of the sodium-coupled choline transporter CHT is regulated acutely by peroxynitrite. Mol. Pharmacol. 73, 801-812. doi: 10.1124/mol.107.040881

Pul, R., Dodel, R., and Stangel, M. (2011). Antibody-based therapy in Alzheimer's disease. Expert Opin. Biol. Ther. 11, 343-357. doi: 10.1517/14712598.2011. 552884

Reed, M. N., Hofmeister, J. J., Jungbauer, L., Welzel, A. T., Yu, C., Sherman, M. A., et al. (2012). Cognitive effects of cell-derived and synthetically-derived $A \beta$ oligomers. Neurobiol. Aging 32, 1784-1794. doi: 10.1016/j.neurobiolaging. 2009.11.007

Ribeiro, F. M., Black, S. A. G., Cregan, S. P., Prado, V. F., Prado, M. A. M., Rylett, R. J., et al. (2005). Constitutive high-affinity choline transporter endocytosis is determined by a carboxyl-terminal tail dileucine motif. J. Neurochem. 94, 86-96. doi: 10.1111/j.1471-4159.2005.03171.x

Rylett, R. J., and Schmidt, B. M. (1993). Regulation of the synthesis of acetylcholine. Prog. Brain Res. 98, 161-166.

Salloway, S., Sperling, R., Fox, N. C., Blennow, K., Klunk, W., Raskind, M., et al. (2014). Two phase 3 trials of Bapineuzumab in mild-to-moderate Alzheimer's disease. N. Engl. J. Med. 370, 322-333. doi: 10.1056/NEJMoa 1304839

Sarter, M., and Parikh, V. (2005). Choline transporters, cholinergic transmission and cognition. Nat. Rev. Neurosci. 6, 48-56. doi: 10.1038/nrn1588

Schenk, D. (2002). Amyloid- $\beta$ immunotherapy for Alzheimer's disease: the end of the beginning. Nat. Rev. Neurosci. 3, 824-828. doi: 10.1038/nrn938

Schneeberger, A., Mandler, M., Otawa, O., Zauner, W., Mattner, F., and Schmidt, W. (2009). Development of AFFITOPE vaccines for Alzheimer's disease (AD)-from concept to clinical testing. J. Nutr. Health Aging. 13, 264-267. doi: 10.1007/s12603-009-0070-5

Schroeter, S., Khan, K., Barbour, R., Doan, M., Chen, M., Guido, T., et al. (2008). Immunotherapy reduces vascular amyloid- $\beta$ in PDAPP mice. J. Neurosci. 28 , 6787-6793. doi: 10.1523/JNEUROSCI.2377-07.2008 
Shankar, G. M., Li, S., Mehta, T. H., Garcia-Munoz, A., Shepardson, N. E., Smith, I., et al. (2008). Amyloid- $\beta$ protein dimers isolated directly from Alzheimer's brains impair synaptic plasticity and memory. Nature Med. 14, 837-842. doi: 10.3410/f.1115634.578903

Spencer, B., and Masliah, E. (2014). Immunotherapy for Alzheimer's disease: past, present and future. Front. Aging Neurosci. 6:114. doi: 10.3389/fnagi.2014. 00114

Tayeb, H. O., Murray, E. D., Price, B. H., and Tarazi, F. I. (2013). Bapineuzumab and solanezumab for Alzheimer's disease: is the 'amyloid cascade hypothesis' still alive? Expert Opin. Biol. Ther. 13, 1075-1084. doi: $10.1517 / 14712598.2013 .789856$

Thinakaran, G., Teplow, D. B., Siman, R., Greenberg, B., and Sisodia, S. S. (1996). Metabolism of the "Swedish" amyloid precursor protein variant in neuro2a (N2a) cells. Evidence that cleavage at the " $\beta$-secretase" site occurs in the golgi apparatus. J. Biol. Chem. 271, 9390-9397. doi: 10.1074/jbc.271. 16.9390

Townsend, G. M., Shankar, G. M., Mehta, T., Walsh, D. M., and Selkoe, D. J. (2006). Effects of secreted oligomers of amyloid $\beta$-protein on hippocampal synaptic plasticity: a potent role for trimers. J. Physiol. 572, 477-492. doi: 10.1113/jphysiol.2005.103754

Walsh, D. M., Klyubin, I., Fadeeva, J. V., Cullen, W. K., Anwyl, R., Wolfe, M. S., et al. (2002). Naturally secreted oligomers of amyloid $\beta$ protein potently inhibit hippocampal long-term potentiation in vivo. Nature 416, 535-539. doi: $10.1038 / 416535 a$
Wang, B., Yang, L., Wang, Z., and Zheng, H. (2007). Amyloid precursor protein mediates presynaptic localization and activity of the high-affinity choline transporter. Proc. Natl. Acad. Sci. U S A 104, 14140-14145. doi: 10.1073/pnas. 0704070104

Young-Pearse, T. L., Bai, J., Chang, R., Zheng, J. B., LoTurco, J. J., and Selkoe, D. J. (2007). A critical function for $\beta$-amyloid precursor protein in neuronal migration revealed by in utero RNA interference. J. Neurosci. 27, 14459-14469. doi: 10.1523/JNEUROSCI.4701-07.2007

Zago, W., Buttini, M., Comery, T. A., Nishioka, C., Gardai, S. J., Seubert, P., et al. (2012). Neutralization of soluble, synaptotoxic amyloid $\beta$ species by antibodies is epitope specific. J. Neurosci. 32, 2696-2702. doi: 10.1523/jneurosci.1676-11. 2012

Conflict of Interest Statement: The authors declare that the research was conducted in the absence of any commercial or financial relationships that could be construed as a potential conflict of interest.

Copyright (c) 2017 Cuddy, Seah, Pasternak and Rylett. This is an open-access article distributed under the terms of the Creative Commons Attribution License (CC BY). The use, distribution or reproduction in other forums is permitted, provided the original author(s) or licensor are credited and that the original publication in this journal is cited, in accordance with accepted academic practice. No use, distribution or reproduction is permitted which does not comply with these terms. 